Discussion Papers
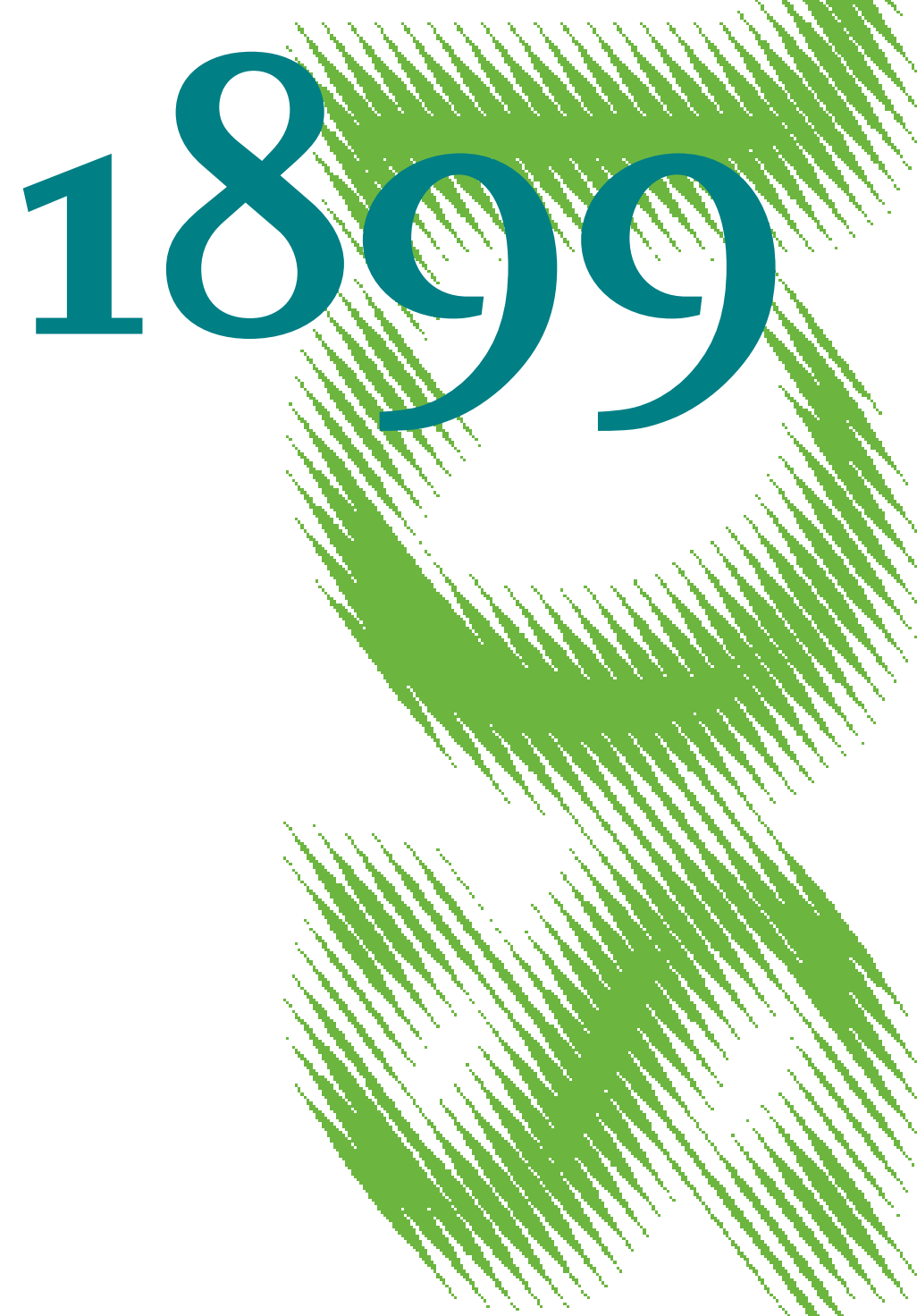

Crisis Impact on the Diversity of Financial Portfolios -

Evidence from European Citizens 
Opinions expressed in this paper are those of the author(s) and do not necessarily reflect views of the institute.

IMPRESSUM

(C) DIW Berlin, 2020

DIW Berlin

German Institute for Economic Research

Mohrenstr. 58

10117 Berlin

Tel. +49 (30) $89789-0$

Fax +49 (30) $89789-200$

http://www.diw.de

ISSN electronic edition 1619-4535

Papers can be downloaded free of charge from the DIW Berlin website:

http://www.diw.de/discussionpapers

Discussion Papers of DIW Berlin are indexed in RePEc and SSRN:

http://ideas.repec.org/s/diw/diwwpp.html

http://www.ssrn.com/link/DIW-Berlin-German-Inst-Econ-Res.html 


\title{
Crisis Impact on the Diversity of Financial Portfolios - Evidence from European Citizens*
}

\author{
Dorothea Schäfer ${ }^{\dagger} \quad$ Michael Stöckel ${ }^{\ddagger} \quad$ Henriette Weser ${ }^{\S}$
}

\begin{abstract}
Since the 2008 Lehman bankruptcy, it is clearly shown that global economic and financial crises present major challenges to private households, requiring from them, a high level of shock absorption capacity. According to the old adage, "Do not put all the eggs in one basket", resilience depends, to a large extent, on financial diversification. So far, especially for Europe, little is known about whether and how the Global Financial Crisis (GFC) affected the diversity of private households' investment portfolios. We tackle this research gap and explore the impact of the GFC on portfolio diversity of European private households. Our European focus complements Sierminska and Silber (2019) who explore the diversification behaviour of US households after the Lehman insolvency. Our study reveals a significant decrease in the diversity of financial portfolios. This finding is robust across distinct model specifications. In response to the GFC, evidence suggests that European households adjusted the diversity of their financial portfolio in the opposite directions to that of US households.
\end{abstract}

Keywords: financial and economic crisis, household finance, portfolio diversification, Shannon entropy index, Gini-Simpson diversity index, background risk, risk aversion JEL classifications: D14, G11, G01, G40

\footnotetext{
${ }^{*}$ We thank Christopher F Baum, Doris Neuberger and Andreas Stephan for their valuable comments and suggestions. This paper is part of the research project The impact of the financial and economic crisis on the diversity of private households' financial portfolios within the Leibniz Research Alliance (LFV) Crises in a Globalized World, Financial market and Debt Crises, https://www.leibnizgemeinschaft.de/en/research/leibniz-research-alliances/crises-in-a-globalised-world.html. The usual disclaimer applies.

†Corresponding author: dschaefer@diw.de, DIW Berlin, Germany; Jönköping University, Sweden; and CERBE, Italy

${ }^{\ddagger}$ michael.stoeckel@posteo.de

§hweser@diw.de, DIW Berlin and Freie Universität Berlin
} 


\section{Contents}

1 Introduction 1

2 Literature Review $\quad 3$

3 Data and Methodology $r$

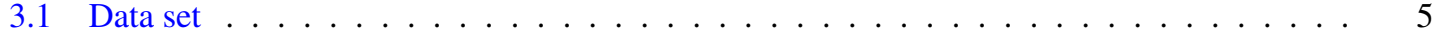

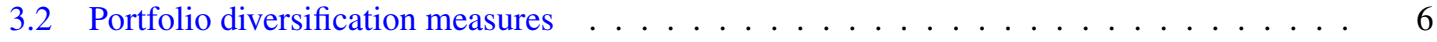

3.3 Crisis indicator and socio-demographic characteristics . . . . . . . . . . . 6

3.4 Evolution of financial portfolio diversity . . . . . . . . . . . . . . . . 8

3.5 Estimation approach $\ldots \ldots \ldots \ldots \ldots \ldots$

4 Results $r$

4.1 Basic model . . . . . . . . . . . . . . . . . . . . . . . 10

4.2 Life events model . . . . . . . . . . . . . . . . . . . . . . 11

4.3 Panel estimation . . . . . . . . . . . . . . . . . . . . . . . . . 12

4.4 Robustness test . . . . . . . . . . . . . . . . . . . . . . . 12

4.4.1 Margins and marginal effects . . . . . . . . . . . . . . . . 12

4.4.2 Unbalanced panel and propensity score matching . . . . . . . . . . . . . 13

5 Conclusion $r$ 


\section{Introduction}

How did the Lehman insolvency and the subsequent series of considerably severe economic shocks affect the diversity of individual financial portfolios? Did individuals take action to change their portfolios' diversity in response to the Global Financial Crisis? The Lehman bankruptcy and the Corona crisis both show that financial and economic turmoils present major challenges not only to banks and businesses but also to ordinary people. Accordingly individuals need considerable coping and shock absorption capacity. Portfolio diversification is an essential part of this. The old adage says "do not put all your eggs in one basket". High losses are simply less likely if the portfolio holder spreads their savings over a large number of asset types. Accordingly, the resilience of households depends, to a large extent on the stability of their asset portfolios.

However, existing empirical studies reveal that a large portion of private households and individuals hold portfolios comprising only a small subset of available asset types (Barasinska, Schäfer, and Stephan, 2012; Börsch-Supan and Eymann, 2000; Campbell, 2006; Hochguertel, 2003; King and Leape, 1998). In addition, so far, we know little about what diversification strategies individuals actually pursue in a crisis and what determines those strategies. Pre-crisis research is silent on this issue (DeMiguel, Garlappi, \& Uppal, 2007; Polkovnichenko, 2005) and studies on the effects after a crisis are rare. One exception is Dimmock, Kouwenberg, Mitchell, and Peijnenburg (2016), who find that the financial crisis increased the probability of ambiguity-averse US individuals to sell stocks. Another exception is Sierminska and Silber (2019), who study how US individuals adjusted their financial portfolios after the Lehman shock. We focus on European households. Specifically, we aim to generate more evidence on how a long-lasting crisis affects the degree of diversity in private financial portfolios.

A banking and economic crisis increases background risks for private households (Guiso \& Paiella, 2008). In many European countries GDP per capita dropped and unemployment figures rose after 2008 (Figure 1). Accordingly, the majority of European citizens faced a higher risk of becoming unemployed. Unemployment threatens the income and wealth position of private households. A slump in stock prices (Figure 1) and in real estate markets following the Lehman bankruptcy (OECD, 2020b) strengthened the perception of increased financial risks.

Individuals may respond to such threats by lowering their portfolio risk, thus implying a higher level of asset diversity. On the other hand, after 2008, low interest rates for safe asset types, like bank savings accounts quickly prevailed across Europe (Figure 1). When observing these shrinking returns, individuals may have been tempted to bet on higher returns, which means that they would have liquidated safe but low return assets for financial securities with a higher risk-return profile (Caju, 2012; Rupprecht, 2018). ${ }^{1}$ These

\footnotetext{
${ }^{1}$ In terms of portfolio size, a lower interest rate could imply decreasing saving rates and, thus, a slowing growth or even a decrease of portfolio size. On the other hand, low interest rates upgrade the value of existing assets that would increase the portfolio size.
} 
opposing conjectures call for more analysis of the adjustments in portfolio diversity that individuals made during the crisis period, and its determinants.

Figure 1 here

To test the contrasting predictions, we employ two commonly used diversity indicators, the GiniSimpson and the Shannon Entropy Index (Shannon, 1948; Simpson, 1949). Specifically, by controlling for socio-demographic characteristics, we examine which diversification strategies European individuals pursued after having experienced considerable economic shocks. In addition, we assess how crucial life changing events during the observation period, such as getting divorced or becoming unemployed, affected their portfolios.

We use the Survey of Health, Ageing and Retirement in Europe (SHARE). SHARE has the advantage of providing harmonized data about the financial situation of older individuals in many European countries. We employ data from wave 2 (2006-2007) and wave 4 (2011-2012). Our data set covers European citizens born in 1964 or earlier. We expect that the crisis' effects are - on average - particularly pronounced in the SHARE age group. Younger individuals may be less sensitive to changing their portfolios in crises than older households. For example, younger household are less risk-averse (Blanchett, Finke, and Guillemette, 2018, Back, Liu, and Teguia, 2019), thus implying a lower incentive to flee to safety when responding to crisis shocks. In addition, they are in the early stage of family, home, and career building, which may imply that the ratio of expenditure to household income is high. Asset portfolios are usually rather small, playing a subordinated role in the young persons' financial planning. Cardak, Martin, and McAllister (2019) provide evidence that older households are more responsive than younger households during financial crises. Accordingly, SHARE is well suited for studying the impact of the Global Financial Crisis on portfolio diversification in a cross-country European context.

We find that the Global Financial Crisis (GFC) induced the observed European households to reduce their financial portfolios' diversity. We also establish that decisive life events, like getting divorced or suffering from health deterioration, do not have a significant impact on portfolio adjustments. This evidence renders the hypothesis obsolete that - instead of the GFC - those life events may have been the driving force behind the diversity reduction in European financial portfolios. The results are highly significant and robust across different model specifications, empirical approaches and sample constructions. The marginal effects per country show a significant decrease in mean value of diversity indicators in Belgium, Denmark, Germany, and the Netherlands.

To the best of our knowledge, we are the first to study how European households adjusted their financial portfolios in response to the Global Financial Crisis. Our analysis is inspired by the US study of Sierminska and Silber (2019), but contrasts strongly in the obtained findings. Accordingly, our research further expands 
the knowledge on the link between a severe crisis and the decisions of individuals on asset diversification in distinct economic, social and financial contexts. We also add to the literature on the resilience of private households and individuals hit by a series of severe economic shocks (Ampudia Fraile, Pavlickova, Slacalek, \& Vogel, 2016). Finally, we provide new evidence about crisis coping strategies of European population cohorts born after World War II, including the baby boomers.

We proceed as follows. In Section 2, we review the current literature concerning asset diversity and crisis reactions. Section 3 describes the data and the empirical approach. Section 4 discusses the findings and Section 5 concludes.

\section{Literature Review}

Cardak et al. (2019) argue "The empirical results provide strong evidence that financial crises cause households to become more myopic, increase their responsiveness to shocks and focus more on past extreme returns". This conclusion suggests that a financial crisis seems not to be the time for financial portfolio diversification despite the fact that the rationality of spreading savings among distinct asset types is a rather old and persistent wisdom. Already in ancient times the Talmud advises to equally spread a person's "money into three; he should bury one-third in the ground, and invest one-third in business [...], and keep one-third in his possession.” Talmud Bavli (n.a.).

In modern times Benartzi and Thaler (2001) call this strategy the " $1 / N$ heuristic". Using this rule implies that the portfolio holder evenly distributes the savings across the $N$ available asset types. DeMiguel, Garlappi, and Uppal (2009) study the effectiveness of the $1 / N$ investment strategy in comparison to 14 different portfolio selection models. The regarded criteria are out-of-sample Sharpe ratio, the certainty equivalent and the turnover of the respective trading strategy on risky assets. The results show that investing according to the $1 / N$ strategy leads to the highest Sharpe ratio and certainty equivalent returns while having a low turnover in comparison to the other investment strategies (DeMiguel et al., 2009). Duchin and Levy (2009) achieve a similar finding for small portfolios when comparing the $1 / N$ strategy to Markowitz's classical mean variance diversification theory. Other research evaluates the reasons why the $1 / N$ strategy outperforms optimal mean variance diversification. Unlike DeMiguel et al. (2009), Hwang, Xu, and In (2018) state that the superior performance of the $1 / N$ rule is rooted in minimized tail risk within small portfolios. This is the risk of high deviation of returns from the standard deviation's mean (Bernstein, 2011). With large portfolios the $1 / N$ strategy still outperforms optimal mean-variance diversification but it acts as compensation for increased tail risk.

Our study focusses on the question of how the Global Financial Crisis affects the households' portfolio diversity. To quantify portfolio diversity and its changes, we use the Gini-Simpson and the Shannon Entropy 
Indexes. Those indices indicate how well the household follows the $1 / N$ portfolio strategy. If the household invests evenly across the distinct asset types both indices would reach its respective maximal value. Yu, Lee, and Chiou (2014) evaluate the performance of selected portfolios considering different entropy measures, like the Shannon Entropy Index. The Gini-Simpson Index is the "diversity twin" of the most popular concentration measure, the Herfindahl Index. As such, it is used in Schaeck, Kick, Onali, and Ruprecht (2014) to study the effects of economic shocks on the degree of concentration of security portfolios held by German households and non-financial firms.

Campbell (2006) examines the investment decisions of US households. He infers from the analysis that flawed investment decisions are related to specific characteristics such as being poor, being poorly educated, or being risk-averse. ${ }^{2}$ Another reason for ineffective investment behavior is that individuals become aware of having too little expertise in portfolio formation. They then tend to withdraw capital from risky assets (Campbell, 2006). Other determinants of portfolio formation found to be important are age, gender (Frijns, Koellen, and Lehnert, 2008, Cardak and Wilkins, 2009, Campbell, 2006), health (Cardak and Wilkins, 2009, Atella, Brunetti, and Maestas, 2012), and home-ownership (Cardak \& Wilkins, 2009). Guiso and Jappelli also find that transaction costs, risk aversion, financial advice, and information costs are relevant factors for diversity levels, while Christelis, Jappelli, and Padula (2010) state that an individual's cognitive abilities are crucial. However, the study by Frijns et al. (2008) underlines that it is not just individual characteristics but also market conditions that have significant influences on portfolio choices.

Market conditions change most significantly in a deep financial and economic crisis. Sierminska and Silber (2019) study the influence of the 2008 financial crisis on US household portfolios. Using different entropy indices and the Gini-Simpson indicator, they quantify how the diversity of financial portfolios changed in response to both the crisis and breaking events in personal lives such as divorce or unemployment. Their evidence reveals that portfolio diversity increased from 2007 to 2009. Another finding is that socio-demographic parameters, such as age, education, income and wealth, as well as the life events, marriage or divorce, affect the diversity in US portfolios.

Sierminska and Silber (2019) report that households in different deciles of the wealth distribution show different degrees of diversity in their portfolios. Hence, wealth changes caused by the GFC are likely to cause portfolio adjustments. Although individuals from high wealth deciles lost more in absolute terms in the crisis, members of low wealth deciles lost more in relative terms (Pfeffer, Danziger, \& Schoeni, 2013). In a study covering Danish individuals, Lyng (2018) provides evidence that wealth characteristics have differing influences on risky asset holdings before and after the crisis. On the basis of register-based panel data from 2004 to 2012, he finds that the crisis changed the elasticity of risky asset holdings to real estate

\footnotetext{
${ }^{2}$ Some investment opportunities, such as investing in commodities, may have too high transaction costs for private households, such that they shy away from including them in their portfolios, despite the possible potential to achieve a better diversified portfolio (Izadi \& Hassan, 2018).
} 
expenses. In post crisis times the increase of real estate expenses reduced risky asset holdings more than it did prior to the crisis.

Our main data source is the Survey of Health, Ageing and Retirement in Europe (SHARE). This data set is commonly used to study the impact of personal characteristics on financial choices (SHARE, 2020a). Atella et al. (2012) evaluated the relationship between health care system, health status and risky assets in households' portfolios. Christelis et al. (2010) employ the SHARE database to understand the influence of cognitive abilities, such as verbal fluency, mathematical skills, and recall abilities, on portfolio decisions. Lindeboom and Melnychuk (2015) analyze the effect of symptoms of depression on the willingness to invest in risky assets. They use SHARE data to understand the displacing effect of public pension wealth on other forms of wealth in Belgium. Cho (2014) examines the influence of homeownership on the investment in risky assets.

\section{Data and Methodology}

\subsection{Data set}

SHARE is a "multidisciplinary cross-national panel database of micro data on health, socio-demographic status and social and family networks of about 140,000 individuals" of higher age (42 years or older) covering 27 European countries and Israel (SHARE, 2020b). The survey started with wave 1 in 2004; as of 2020 seven waves are published. In order to observe the diversity of asset holding before and after the GFC we limit our sample to waves 2 and 4, collected before and after the GFC, respectively. The interviews for wave 2 were conducted in 2006 and 2007. Interviews for wave 4 were almost entirely conducted in 2011, thus capturing the situation after the GFC. ${ }^{3}$

The unit of observation is the financial respondent. A financial respondent provides the information on his or her financial situation. Within a couple, the financial respondent delivers the information on behalf of the couple. In a one person household this person is the financial respondent. ${ }^{4}$ SHARE is a very rich dataset for individual characteristics of respondents. However, information on the respondent's risk aversion is available only for wave 2 . By including the risk aversion into the estimation model, we implicitly assume that the respondents' risk aversion remains constant over the crisis.

We require a balanced panel in order to observe one and the same household twice, prior to and post the GFC. The balancing shrinks the sample and the number of countries considerably, leaving us with 4826 observations in 12 countries, thus 2413 per wave. The reduced sample size may have some influence on the

\footnotetext{
${ }^{3}$ The interviews in Poland for wave 4 were conducted in 2012, except one observation. In 10 exceptional cases, wave 4 interviews for Germany were conducted in 2012 .

${ }^{4} \mathrm{~A}$ multi person household may have more than one financial respondent. In our dataset $99.92 \%$ of households are solely represented by one financial respondent per wave.
} 
findings. Therefore, we conduct, in addition to the main analysis, a robustness check using the unbalanced panel of both waves and, additionally, apply a propensity score matching approach.

\subsection{Portfolio diversification measures}

To quantify the change in the diversity of a private household's financial portfolio we apply two commonly used measurements of diversity (Simpson, 1949, Thukral, 2017, Spellerberg and Fedor, 2003). The first one is the Gini-Simpson Index,

$$
\text { DIV1 }=1-\sum_{i=1}^{N} S_{i}^{2}
$$

with $S_{i}$ as the value share of asset type $i$ in the household portfolio's value and $N$ as the number of different asset types. This index was constructed by Simpson (1949) in order to measure concentration independent of sample size. ${ }^{5}$ The second index is called Shannon Entropy ${ }^{6}$ Index (Shannon, 1948), ${ }^{7}$

$$
\operatorname{DIV} 2=-\sum_{j=1}^{N} S_{i} \ln S_{i}
$$

$-\ln S_{i}$ is particularly large for small shares. Accordingly, the weight of small shares is larger in Index (2) than in Index (1). Both indicators are at the maximum if the portfolio owner distributes her or his wealth evenly across the distinct asset types so that each asset type's share is $1 / N$.

\subsection{Crisis indicator and socio-demographic characteristics}

The main variable of interest in the basic model is the dummy variable post crisis. It estimates the impact of the GFC on the diversity of financial asset holdings. The variable takes on the value zero if the respondents portfolio is observed prior to the Lehman insolvency and one if the observation date is post the insolvency. ${ }^{8}$ We add two demographic variables representing gender and age. female is a binary variable with value one if the respondent is a woman and zero if a man. Age takes on three categories, 60 years or younger, between 60 and 70 years, or 70 years and older. Table 2 reveals that the gender distribution of respondents in the sample is even. The youngest respondent was 42 years old and the oldest was 92 years at the time of the 2006/2007 survey.

The level of education is captured as a categorical variable education group: no education, less than

\footnotetext{
${ }^{5}$ The Index is suitable for an infinite population in which every individual has a group affiliation with a respective proportion of individuals in each group (Simpson, 1949). For an overview of diversity indicators in financial economics, see also Michie and Oughton (2013).

${ }^{6}$ Entropy in a discrete case measures randomness of a chance variable. For evaluating economic diversification on macro level entropy measures are a common instrument as used by Ali and Cantner (2020) to explore the effect of economic diversification on human development and welfare.

${ }^{7}$ Claude Shannon was a mathematician with a focus on information communication. The original objective was to quantify the risk in predicting the next letter in a message or reproducing the exact or approximate message from one point to another point (Spellerberg and Fedor, 2003, Shannon, 1948).

${ }^{8}$ We use the terms post crisis and post Lehman insolvency interchangeably.
} 
high school, high school, some university studies, university degree, and other education. Some university studies is equivalent to the first stage of secondary education. On average, respondent education level is high school. The number of children and a dummy variable with value one if she or he is married, and zero otherwise, indicate the family situation. To account for the employment status we use the variable labor group with the categories dependent working, self-employed, other occupation, retiree and unemployed. The variable risk group indicates the respondent's self perceived risk aversion and takes on one of four values: not any risk (not willing to take any financial risks), average risk (take average financial risks expecting to earn average returns), above average risk (take above average financial risks expecting to earn above average returns), and substantial risk (take substantial financial risks expecting to earn substantial returns). Table 2 reports for the risk group a mean of less than 1.5. This indicates that the respondents are, on average, rather risk averse.

Another important socio-demographic characteristic is the total net income per year. We construct four income groups: Poor (below euro 25000), lower middle-class (between euro 25000 and euro 50000), upper middle-class (between euro 50000 and euro 100000), and rich (above euro 100000). On average, individuals are located in the lower middle-class income group. In addition, we account for the individual's position in the country's wealth distribution. Specifically, we accumulate the wealth components (financial, property, and capital wealth) per person and subtract debt where applicable. Then, we aggregate the accumulated net wealth of the respondents, per country and wave, and split the accumulated amounts into deciles. Finally, we allocate each respondent into one of the ten wealth deciles. The wealth classes are calculated for each of the twelve countries separately. This is necessary as wealth differences between the countries in the sample might be substantial. On average, the sample's respondents are located roughly in the middle of their home country's wealth distribution (see Table 2). Additionally, we use homeownership as an additional wealth variable. Home owners may have less diversified financial portfolios as most of their wealth is locked in the property investment. Finally, we include country dummies to capture country specific effects.

Table 1 here

To analyze whether specific events in the respondent's life may have determined the change in portfolio diversity during the crisis, we specify a second model focusing on the effect of crucial life events occurring between 2006/2007 and 2011/2012, and on the impact of a change in the total value of the portfolio, $P F$ value change. Specifically, we construct dummy variables taking on the value of one, and zero otherwise, if the respondent got divorced, stopped working, experienced a deteriorating health (health became worse) or had children in 2011/2012 while being without children in 2006/2007. All variables are explained in Table 1. Table 2 reports the summary statistics of the socio-demographic variables. 


\subsection{Evolution of financial portfolio diversity}

Table 3 shows the value share per asset type for the complete sample pre and post Lehman insolvency. For each asset type we aggregate the values across all respondents and divide this value by the value of all assets in the sample. We find an extreme value concentration in safe asset holding of over 99 percent in both waves. Fairly safe assets account for $0.03 \%$ in $2006 / 2007$ and $0.2 \%$ after the Lehman insolvency. The value share of risky assets behaved similarly and made up for $0.04 \%$ of assets value before the crisis and $0.4 \%$ in $2011 / 2012$. These shares differ strongly from the findings in Sierminska and Silber (2019) for US household portfolios. Their post Lehman insolvency wave covers 2009 and they calculate a $13.9 \%$ share of safe assets and a $13.2 \%$ share of fairly safe assets. The remaining $72.9 \%$ of wealth is invested in risky assets. The differences in shares between pre and post Lehman insolvency are statistically significant.

Table 3 here

Table 4 reports the ownership rate per asset type independent of asset value before and after the Lehman insolvency. This rate depicts the percentage of financial respondents who own a particular type of asset. Again, the respondents show a strong concentration toward safe assets prior and, even stronger, post the Lehman insolvency. $33.4 \%$ of financial respondents in 2006/2007 and 27.4\% in 2011/2012 possess fairly safe assets. $45.0 \%$ and $41.1 \%$, respectively, have risky assets in their portfolio. The increase in ownership rates of safe assets and the reduction in fairly safe assets as well as risky assets is statistically significant.

Table 4 here

Again, the observed rates reveal a considerable contrast to the US evidence in Sierminska and Silber (2019). In 2009, $43.0 \%$ of households in the US sample possessed fairly safe assets and $74.3 \%$ owned any amount of risky assets.

Table 5 reports the values of the diversity indicators DIV1 and DIV2 per country and date. We distinguish between diversity in asset types and diversity in risk content. The descriptive findings indicate decreasing levels of diversity in the financial portfolios over the years in a great majority of countries. These numbers give a first indication of how the level of financial portfolio diversity has evolved over the crisis. In the next section, we dig deeper to distill the impact of the GFC, and apply multivariate statistical approaches that control for the relevant socio-demographic characteristics.

Table 5 here

\subsection{Estimation approach}

We aim to identify how European households adjusted their financial portfolios in response to the GFC. In addition, we assess whether European households responded differently to the crisis to what Sierminska 
and Silber (2019) report for US households. To allow for this comparison, our basic specification applies a similar pooled OLS regression approach to the SHARE data,

$$
D I V_{i t}=\gamma D+\beta X_{i}+\alpha Z_{i t}+\epsilon_{i t}
$$

The main variable of interest in the OLS regression equation (3) is the year-dummy $D$ representing the post crisis wave. By including the post crisis dummy variable $D$, we account for the GFC effects on all households in the considered European countries. The sign of the coefficient $\gamma$ reveals whether the portfolio diversity has increased or decreased in response to the crisis. Matrix $X_{i}$ represents the time-invariant control variables, like the female dummy variable, the four categorial variables respresenting the risk group and the country dummies. The second matrix $Z_{i t}$ represents the time-variant characteristics for individual $i$ in period $t$ : the variables are the categorical variables age group, education group, labor group, income group and wealth deciles, as well as the continuous variable number of children and the dummy variables married and home owner. The second specification explores the impact of crucial life events on the probability of increasing the portfolio diversity in the crisis period. The life events model is designed to assess whether significant changes in the respondent's life trigger diversity adjustments in the financial portfolio instead of the GFC. Specifically, we apply a pooled logistic regression with

$$
y_{i, \text { post crisis }}= \begin{cases}1 & \text { if the difference in portfolio diversity, } \Delta \operatorname{DIV}_{i, \text { post crisis }}, \text { is positive } \\ 0 & \text { if the difference in portfolio diversity, } \Delta \operatorname{DIV}_{i, \text { post crisis }}, \text { is zero or negative. }\end{cases}
$$

The estimation equation is

$$
\operatorname{Prob}\left[\Delta y_{i, \text { post crisis }}=1\right]=\frac{e^{z}}{1+e^{z}}
$$

where

$$
z=\sigma_{i}+\beta X_{i}+\alpha Z_{i, \text { post crisis }}+\delta \text { events }+\epsilon_{i, \text { post crisis }}
$$

and therefore,

$$
\operatorname{Prob}\left[\mathrm{DIV}_{i, \text { post crisis }}>0\right]=\Lambda\left(\sigma_{i}+\beta X_{i}+\alpha Z_{i, \text { post crisis }}+\delta \text { events }+\epsilon_{i, \text { post crisis }}\right)
$$

$\Lambda(\cdot)$ denotes the logistic cumulative distribution function. The $\sigma_{i}$ is the individual specific effect. $X_{i}$ reflects the time-invariant explanatory variables and $Z_{i}$ the time-variant characteristics. Equation (4) estimates the impact of crucial life events on the probability of increasing the portfolio diversity in the crisis period ( $\Delta$ $\mathrm{DIV}_{i \text {,post crisis }}>0$ ). We define as crucial life events divorce, deteriorated health, job loss or changing from being childless to having children. Gender, risk aversion, both time invariant, and the time variant variables 
age, education, income, wealth, as well as a categorical country variable are the controls. All control variables are taken from the post Lehman insolvency period. The estimated coefficients are odds ratios. Finally, we run a panel data estimation. Specifically, we apply a correlated random effects (CRE) model (Perales, 2013),

$$
D I V_{i t}=\gamma D_{t}+\beta X_{i}+\alpha Z_{i t}+\tau_{1} \bar{Z}_{i t}+\epsilon_{i t}
$$

The approach controls for the unobserved effects and allows them to be correlated with the regressors by adding the time-averaged values of the time-variant regressors. ${ }^{9}$ The panel estimation is also a robustness test for the pooled OLS approach in equation (3).

\section{Results}

\subsection{Basic model}

Table 6 reports the results from estimating the basic model described in equation (3). Columns (1) and (2) show the coefficients of the model without wealth deciles and the home owner variable, Column (3) and (4) include the respondents' wealth position, while Columns (5) and (6) present the results from the full model with home ownership. The main variable of interest, post crisis, obtains a consistently negative and highly significant coefficient across all specifications. This finding indicates that European households were highly sensitive to the GFC when it comes to financial portfolio decisions. The households reduced the diversity of their financial portfolios in response to the crisis. The direction of the effect obtained for European households is in strong contrast to Sierminska and Silber (2019) on US households. They find a highly significant and positive effect of the GFC on portfolio diversity.

To some extent surprising, gender has no significant impact on portfolio diversity. The effect of female is captured by the categorical variables representing distinct risk attitudes. ${ }^{10}$ Any category above the base category not any risk shows a highly significant and positive coefficient, no matter how diversity is measured. Relative to the base category, respondents with less risk aversion have better diversified portfolios.

In contrast to the US evidence, we find that the oldest cohort has significantly less diversified portfolios than the youngest cohort across all specifications (Sierminska \& Silber, 2019). In line with expectations and the literature, education works in favour of portfolio diversity. Individuals with education less than high school, high school and some university studies show higher portfolio diversity than the persons in the base category no education. The coefficients become larger, the higher is the level of education. The number of children works significantly against diversification of the financial portfolio, suggesting family size matters for portfolio diversification. Being retired negatively affects portfolio diversity significantly relative to the

\footnotetext{
${ }^{9}$ The coefficients are identical to the fixed effects coefficients on the time-variant regressors.

${ }^{10}$ When estimating the models without the variables representing risk attitude, gender is significant and negative.
} 
base category, which consists of employed people.

All income and wealth categories above the base categories show highly significant and positive coefficients. The only exception is home ownership (see Columns (5) and (6)). The jump from lower middle-class (income between 25000.5 euros and 50000.5 euros) to the upper middle-class (income between 50000.5 euros and 100000.5 euros) leads in most specifications, to a strong increase in portfolio diversity, whereas the difference in the coefficients between the two higher income categories is rather small. The coefficients of the wealth deciles also tend to become larger, the higher is the individual's position in the wealth distribution. Accordingly, the analysis clearly shows that richer people own better diversified portfolio. This finding is, to some extent in line with Sierminska and Silber (2019) for the US and is also supported by Guiso and Jappelli (2005) who analyze a sample of clients from the largest Italian bank UniCredit. Sierminska and Silber (2019) obtain highly significant and increasing coefficients but only for the highest wealth deciles and negative ones for the wealth deciles directly above the base category. Being a home owner is negatively associated with financial portfolio diversity and the coefficient is highly significant. This finding may indicate that European home owners are usually required to have their wealth concentrated in their home equity, making them presumably especially prone to focus only on a very limited amount of assets.

\section{Table 6 here}

The findings on the control variables are, to some extent, compatible with pre-crisis evidence on US portfolios, e.g. Bertaut and Starr (2000) who analyze how age, income risk, education and wealth influences the composition of household portfolios. However, by and large, we can infer from the so far obtained evidence and the comparison with Sierminska and Silber (2019) that, in terms of portfolio diversity, European households respond to the GFC very differently than US households.

\subsection{Life events model}

The life events model assesses whether significant changes in the respondent's life, instead of the GFC, are responsible for the diversity adjustments in the financial portfolios. Table 7 reports the results of the estimations based on equation (4). All life-event dummy variables receive insignificant coefficients, thus indicating that these events have no impact on the likelihood of a diversity adjustment in the financial portfolio during the crisis.

Table 7 here

The only exception is a change in the total value of the portfolio ( $P F$ value change). An increase in the total value of the portfolio is associated with a higher probability of increasing portfolio diversity and vice versa. The lower part of Figure 2 shows that close to $60 \%$ of individuals in the lowest wealth decile suffered 
from a reduction in financial wealth during the GFC. This makes them more likely to reduce their portfolio diversity. In higher wealth classes, except the highest, the percentage of individuals with a gain in financial wealth over the GFC is larger than the percentage with a loss. Gainers are particularly frequent in the second and the third wealth classes. Almost $60 \%$ of the second and third wealth decile experienced an increase. The upper part of Figure 2 shows that the response of individuals in adjusting the diversity of their portfolio strongly correspondents with wealth deciles. One reason for this behavior may be that in lower wealth deciles, the amount of wealth is too small to cover the cost of distributing it over many assets.

Figure 2 here

\subsection{Panel estimation}

Table 8 reports the results of the CRE estimation based on equation (5). The model specification is equivalent to Columns (5) and (6) of Table 6. The coefficient of post crisis remains negative and highly significant in the panel estimation, thus indicating that individuals reduced the diversity of their financial portfolios in response to the GFC and confirming the respective results from the pooled regression. The coefficient for the variable number of children shows a strong and positive sign implying that the household's financial decision maker tends to increase portfolio diversity as the number of children within the household increases. The strongly negative impact of retiree on portfolio diversity and the strongly positive effect of higher wealth is also already known from the pooled regression approach. In contrast, home ownership loses its significance in the panel estimation rendering some doubts about the robustness of the impact of this variable found in the pooled regression. ${ }^{11}$

Table 8 here

Importantly, the panel estimation confirms again that the portfolio response of European individuals to the GFC strongly differs from the response of US individuals as reported in Sierminska and Silber (2019).

\subsection{Robustness test}

\subsubsection{Margins and marginal effects}

The effect of the post crisis variable may differ depending on what personal characteristics the respondent has as well as which circumstances and environments the individual faces. For example, the effect of the GFC on the respondent's portfolio diversity may vary from country to country, it may change with the respondents' education level, marital status, risk aversion, etc. To account for these potential contingencies,

\footnotetext{
${ }^{11}$ Pelizzon and Weber (2009) report a significant effect of housing on efficient portfolios.
} 
we run a regression interacting the post crisis variable with all other covariates,

$$
D I V_{i t}=\gamma D \times\left(\beta X_{i}+\alpha Z_{i t}\right)+\epsilon_{i t}
$$

and calculate the Average Marginal Effect (AME) for post crisis and the other covariates. Table 9 shows the results. The marginal effect of post crisis is highly significant for both diversity measures confirming the previous findings of a strong negative impact of the GFC on the level of diversity in households' financial portfolios.

Given that the European Union is "united in diversity", the portfolio response of individuals to the GFC is unlikely to be the same across European countries. Table 5 is a first indication that financial portfolio adjustments during the crisis differ. While in most countries the average diversity values have decreased over the crisis years, there are also some countries in which values have increased, such as Spain and Poland. These differences are not significant. The margins approach enables us to disentangle the crisisrelated portfolio adjustments across countries.

\section{Figure 3 here}

Figure 3 reveals that portfolio diversity, no matter whether measured with the Gini-Simpson or the Shannon Entropy indicator, significantly decreased over the GFC in Belgium, Denmark, Germany, and the Netherlands, but was statistically non-different from zero in the other countries.

The distinct background risk arising from the respondent's occupational status is another interesting source for a potentially differing crisis response. Figure 4 illustrates the marginal effects of post crisis for distinct occupational groups. Dependent workers and retirees significantly decreased their level of diversification while facing the GFC. Unemployed and self-employed persons as well as respondents with other occupational statuses show no significant crisis response.

\section{Figure 4 here}

\subsubsection{Unbalanced panel and propensity score matching}

The unbalanced data set comprises 20848 observations, 7978 respondents in the 2006/2007-wave and 12870 persons in the 2011/2012-wave. When we balance the panel to ensure that each household is observed in both waves, we lose around 15000 observations. The main reason for the data loss is the risk group variable. As this indicator is only observed in wave 2, no such information is available for households not observed in wave 2 but observed in wave 4 . Households which are only found in wave 4 thus have missing values. In order to have an informative data set we usually drop observations with missing values. Hence, in this regression we use female as the proxy for risk aversion instead of the risk group variable. 
This adjustment allows for preserving the large panel. To see whether this considerable data loss due to balancing is meaningful for our main findings, we apply a similar pooled regression approach (equation 3) to the unbalanced data set as we did in Table 6.

The results on the response to the GFC using the unbalanced data set confirm the previous findings (Table 10). We obtain again highly significant and negative coefficients of the post crisis variable indicating a reduction of portfolio diversity during the crisis period. As expected female representing higher risk aversion becomes negative and significant, implying that increased risk aversion has a negative impact on portfolio diversification.

Table 10 here

To drive the robustness analysis further, we apply propensity score matching on the unbalanced data set and run the regression on the matched sample. The results for the matched sample resemble the findings from Table 10 and confirm again the negative impact of the GFC on portfolio diversity. As in the non-matched sample, women hold less diversified portfolios than men, which implies a negative relationship between risk aversion and diversity. ${ }^{12}$

\section{Conclusion}

This paper answers the question of whether the 2008/09 Global Financial Crisis affected the financial portfolio's diversity of settled private households in Europe and puts the findings into perspective of evidence obtained from the US. The sample households from 12 European countries are observed regularly in the SHARE survey. Two common diversity indices (Gini-Simpson Index and Shannon Entropy Index) quantify the diversity levels of the households' financial portfolios. We focus on two waves, the wave before and the wave after the Lehman insolvency.

The basic pooled OLS regression reveals that the estimated coefficient on the post crisis time dummy variable is consistently significant and negative for both diversity indices and across different specifications. We also test whether life affecting events such as becoming unemployed or getting children lead to a change in diversity levels of financial portfolios. Neither of these events significantly affects the likelihood of increasing portfolio diversity. The only change that is likely to trigger adjustments over the GFC is a change in the portfolio's value. A value gain increases the likelihood of greater diversity, and vice versa. As life affecting events show no influence on the likelihood of changing portfolio diversity, we infer from this evidence that it is the GFC that is responsible for the reduction of diversity levels in European household portfolios between 2007 and 2011. Wealth and income class matter for portfolio diversity. The higher the household is located in the income and wealth pyramid the more diverse is its financial portfolio.

\footnotetext{
${ }^{12}$ The respective regression Table is available from the authors upon request.
} 
The willingness to take risks works in favor of portfolio diversity. As we cannot observe the financial respondents' risk aversion in the post crisis wave, we cannot exclude that the GFC has made the European households more risk averse. Accordingly, part of the observed reduction in portfolio diversity could be the effect of a possibly increased personal reluctance to take risks. However, even if this is the case, the GFC would remain the deeper cause behind the less diverse financial portfolios in the post crisis wave.

The loss of asset diversity during the crisis may be rooted in an increased mistrust in financial markets as well as a flight to safety and liquidity. Portfolio diversity may also have decreased because of generally decreased values of risky assets. Remarkably, European households with decision makers born in 1964 or older adjusted their financial portfolio's diversity in response to the Global Financial Crisis in the opposite direction than the existing evidence on US household portfolios would suggest. Further research should explore the reason for the large differences between the US and European countries. The data also shows a strong disadvantage for households from lower income groups or wealth deciles. These individuals diversify their portfolios less than higher income groups or wealth classes which may lead to lower resilience in case of a shock. In order to minimize the losses for the economically weaker parts of society it is necessary to understand the investment possibilities and behaviour of these groups. Studying whether and how much individuals in the low income or low wealth deciles are saving, and whether they face particular severe barriers when attempting to take part in the financial market is important. Such barriers include high fees for deposits and other additional costs related to the savings account or a lack of information and, related to that, high costs in acquiring needed information.

\section{References}

Ali, M., \& Cantner, U. (2020). Economic diversification and human development in europe. Eurasian Economic Review, 10, 1-25.

Ampudia Fraile, M., Pavlickova, A., Slacalek, J., \& Vogel, E. (2016). Household heterogeneity in the euro area since the onset of the great recession. Journal of Policy Modeling, 38(1), 181-197.

Atella, V., Brunetti, M., \& Maestas, N. (2012). Household portfolio choices, health status and health care systems: A cross-country analysis based on share. Journal of banking \& finance, 36(5), 1320-1335.

Back, K., Liu, R., \& Teguia, A. (2019). Increasing risk aversion and life-cycle investing. Mathematics and Financial Economics, 13(2), 287-302.

Barasinska, N., Schäfer, D., \& Stephan, A. (2012). Individual risk attitudes and the composition of financial portfolios: Evidence from German household portfolios. The Quarterly Review of Economics and Finance, 52(1), 1-14. Retrieved from http ://www . sciencedirect . com/science/article / pii / S1062976911000615 
Benartzi, S., \& Thaler, R. H. (2001). Naive diversification strategies in defined contribution saving plans. American economic review, 91(1), 79-98.

Bernstein, A. (2011). Retrieved from https://www.alliancebernstein.com/abcom/Int/DE/content/Research/ Instrumentation/Hedging-Tail-Risk-ABEurope_A4-20111004.pdf

Bertaut, C. C., \& Starr, M. (2000). Household portfolios in the united states.

Blanchett, D., Finke, M., \& Guillemette, M. (2018). The effect of advanced age and equity values on risk preferences. Journal of Behavioral Finance, 19(4), 434-441. Retrieved from https://doi.org/10.1080/ 15427560.2018 .1431884

Börsch-Supan, A., \& Eymann, A. (2000). Household portfolios in Germany. Beiträge zur angewandten Wirtschaftsforschung, No. 603-01, Institut für Volkswirtschaftslehre und Statistik, Universität Mannheim.

Caju, P. D. (2012). Asset formation by households during the financial crisis. Economic Review, (1), 87100.

Campbell, J. Y. (2006). Household finance. The journal of finance, 61(4), 1553-1604.

Cardak, B. A., Martin, V. L., \& McAllister, R. (2019). The effects of the global financial crisis on the stock holding decisions of australian households. The North American Journal of Economics and Finance, 50, 100983. Retrieved from http://www.sciencedirect.com/science/article/pii/S1062940818305552

Cardak, B. A., \& Wilkins, R. (2009). The determinants of household risky asset holdings: Australian evidence on background risk and other factors. Journal of banking \& Finance, 33(5), 850-860.

Cho, I. (2014). Homeownership and investment in risky assets in europe. Review of European Studies, 6(4), 254.

Christelis, D., Jappelli, T., \& Padula, M. (2010). Cognitive abilities and portfolio choice. European Economic Review, 54(1), 18-38.

DeMiguel, V., Garlappi, L., \& Uppal, R. (2007). Optimal versus naive diversification: How inefficient is the 1/n portfolio strategy? The Review of Financial Studies, 22(5), 1915-1953.

DeMiguel, V., Garlappi, L., \& Uppal, R. (2009). Optimal versus naive diversification: How inefficient is the 1/n portfolio strategy? The review of Financial studies, 22(5), 1915-1953.

Dimmock, S. G., Kouwenberg, R., Mitchell, O. S., \& Peijnenburg, K. (2016). Ambiguity aversion and household portfolio choice puzzles: Empirical evidence. Journal of Financial Economics, 119(3), 559-577. Retrieved from http://www.sciencedirect.com/science/article/pii/S0304405X16000040

Duchin, R., \& Levy, H. (2009). Markowitz versus the talmudic portfolio diversification strategies. The Journal of Portfolio Management, 35(2), 71-74.

Eurostat. (2020). Arbeitslosenquote nach geschlecht, alter und staatsangehörigkeit(\%). Retrieved from http s://ec.europa.eu/eurostat/de/web/products-datasets/product?code=lfsa_urgan 
Frijns, B., Koellen, E., \& Lehnert, T. (2008). On the determinants of portfolio choice. Journal of Economic Behavior \& Organization, 66(2), 373-386.

Guiso, L., \& Jappelli, T. (2005). Household portfolio choice and diversification strategies. Trends in Saving and Wealth working paper, 7(05).

Guiso, L., \& Paiella, M. (2008). Risk aversion, wealth, and background risk. Journal of the European Economic Association, 6(6), 1109-1150. Retrieved from https://onlinelibrary.wiley.com/doi/abs/10. 1162/JEEA.2008.6.6.1109

Hochguertel, S. (2003). Precautionary motives and portfolio decisions. Journal of Applied Econometrics, $18(1), 61-77$.

Hwang, I., Xu, S., \& In, F. (2018). Naive versus optimal diversification: Tail risk and performance. European Journal of Operational Research, 265(1), 372-388.

Izadi, S., \& Hassan, M. K. (2018). Portfolio and hedging effectiveness of financial assets of the G7 countries. Eurasian Economic Review, 8(2), 183-213. doi:10.1007/s40822-017-0090-0

King, M., \& Leape, J. (1998). Wealth and portfolio composition: Theory and evidence. Journal of Public Economics, 69, 155-193.

Lindeboom, M., \& Melnychuk, M. (2015). Mental health and asset choices. Annals of Economics and Statistics/Annales d'Économie et de Statistique, (119/120), 65-94.

Lyng, R. S. (2018). The impact of the financial crisis on homeowners' portfolio choice. Available at SSRN 3118891.

Michie, J., \& Oughton, C. (2013). Measuring diversity in financial services markets: A diversity index. Centre for Financial and Management Studies CeFiMS, University of London. Retrieved from http: //www.cefims.ac.uk/cgi-bin/research.cgi

OECD. (2020a). Level of gdp per capita and productivity. Retrieved from https://stats.oecd.org/Index.aspx? DataSetCode $=$ PDB LV

OECD. (2020b). Share prices (indicator). doi:10.1787/6ad82f42-en

OECD. (2020c). Short-term interest rates. Retrieved from https://data.oecd.org/interest/short-term-interestrates.htm

Pelizzon, L., \& Weber, G. (2009). Efficient portfolios when housing needs change over the life cycle. Journal of Banking \& Finance, 33(11), 2110-2121. Retrieved from http://www . sciencedirect.com/ science/article/pii/S037842660900106X

Perales, F. ( (2013). MUNDLAK: Stata module to estimate random-effects regressions adding group-means of independent variables to the model. Statistical Software Components, Boston College Department of Economics. Retrieved from https://ideas.repec.org/c/boc/bocode/s457601.html 
Pfeffer, F. T., Danziger, S., \& Schoeni, R. F. (2013). Wealth disparities before and after the great recession. The ANNALS of the American Academy of Political and Social Science, 650(1), 98-123.

Polkovnichenko, V. (2005). Household portfolio diversification: A case for rank-dependent preferences. The Review of Financial Studies, 18(4), 1467-1502.

Rupprecht, M. (2018). Low interest rates and household portfolio behaviour in euro area countries. Intereconomics: Review of European Economic Policy, 53(3), 174-178. Retrieved from https://ideas.repec. org/a/spr/intere/v53y2018i3d10.1007_s10272-018-0743-6.html

Schaeck, K., Kick, T., Onali, E., \& Ruprecht, B. (2014). Wealth shocks, credit-supply shocks, and asset allocation: Evidence from household and firm portfolios (Working Paper Series No. 1662). European Central Bank. Retrieved from https://ideas.repec.org/p/ecb/ecbwps/20141662.html

Shannon, C. E. (1948). A mathematical theory of communication. The Bell System Technical Journal, 27(3), $379-423$.

SHARE. (2020a). Retrieved from http ://www . share - project . org / share - research - results . html. ((accessed:23.03.2020))

SHARE. (2020b). Retrieved from http://www.share-project.org/data-documentation/release-guides.html. ((accessed:25.03.2020))

Sierminska, E. M., \& Silber, J. (2019). The diversity of household assets holdings in the united states in 2007 and 2009: Measurement and determinants. Review of Economics of the Household, 1-36.

Simpson, E. H. (1949). Measurement of diversity. Nature, (163), 688.

Spellerberg, I. F., \& Fedor, P. J. (2003). A tribute to claude shannon (1916-2001) and a plea for more rigorous use of species richness, species diversity and the 'shannon-wiener'index. Global ecology and biogeography, 12(3), 177-179.

Talmud Bavli. (n.a.). Bava metzia 42a.

Thukral, A. K. (2017). A review on measurement of alpha diversity in biology. Agric. Res. J, 54(1), 1-10.

Yu, J.-R., Lee, W.-Y., \& Chiou, W.-J. P. (2014). Diversified portfolios with different entropy measures. Applied Mathematics and Computation, 241, 47-63. 
Figure 1: Change in main macro indicators from 2007 to 2011

\section{Change 2007-2011}

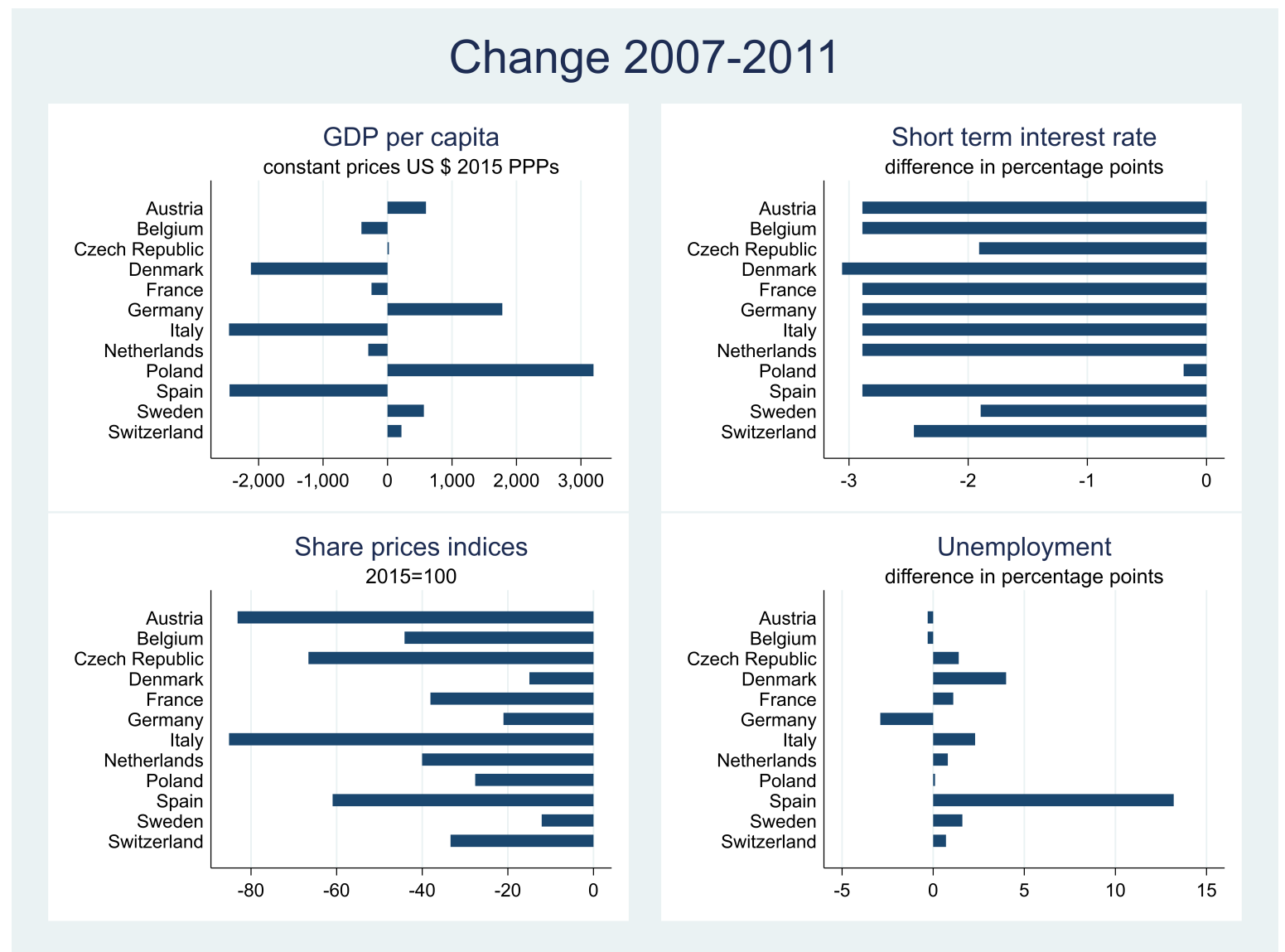

Source: OECD (2020a), Eurostat (2020), OECD (2020b), OECD (2020c) 
Figure 2: Percentage of observations with a gain or loss in wealth and in diversity after the crisis per wealth decile

Share of observations in percent
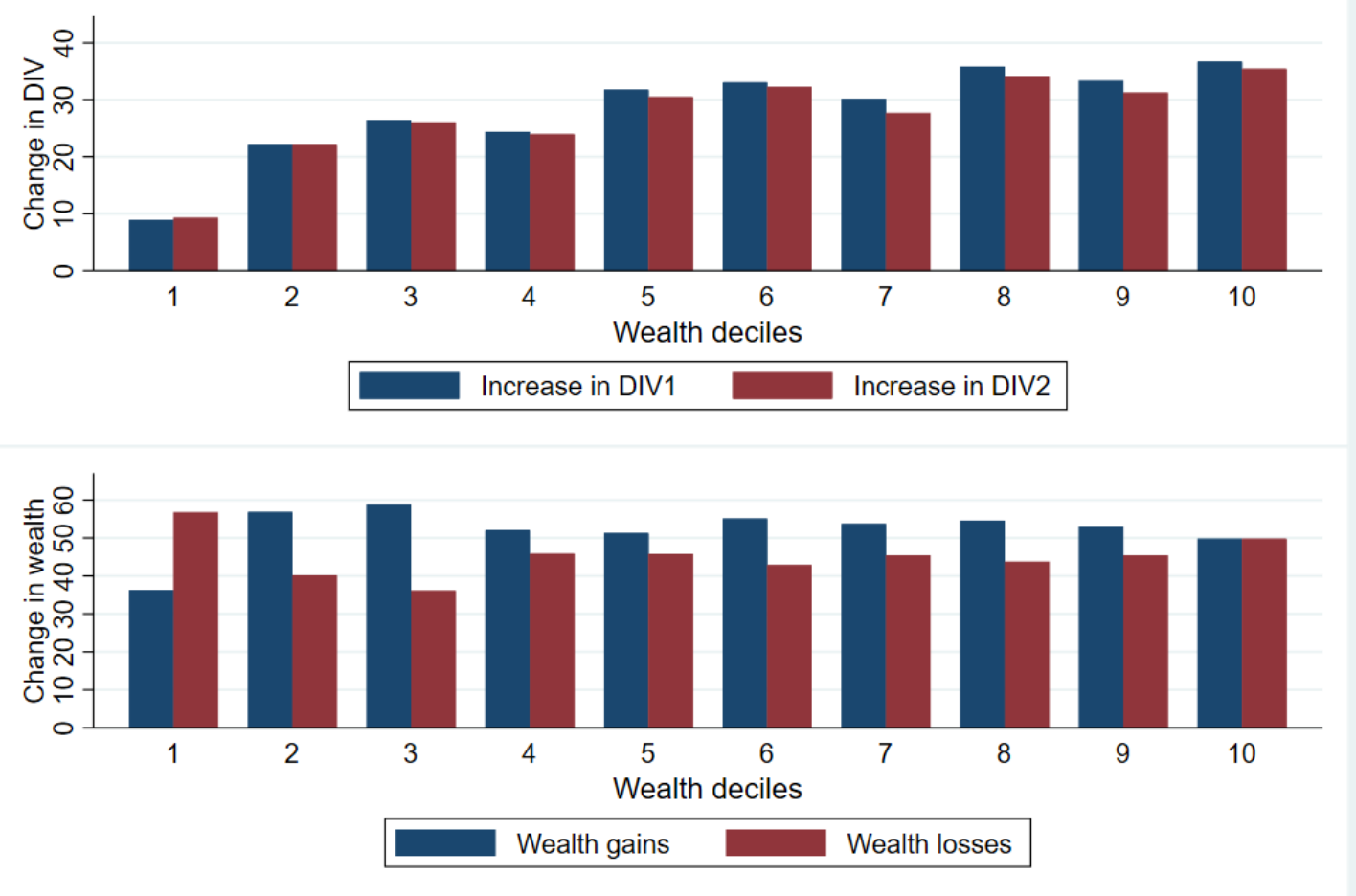

Source: Own calculation 
Figure 3: Marginal effect of GFC on portfolio diversity per country
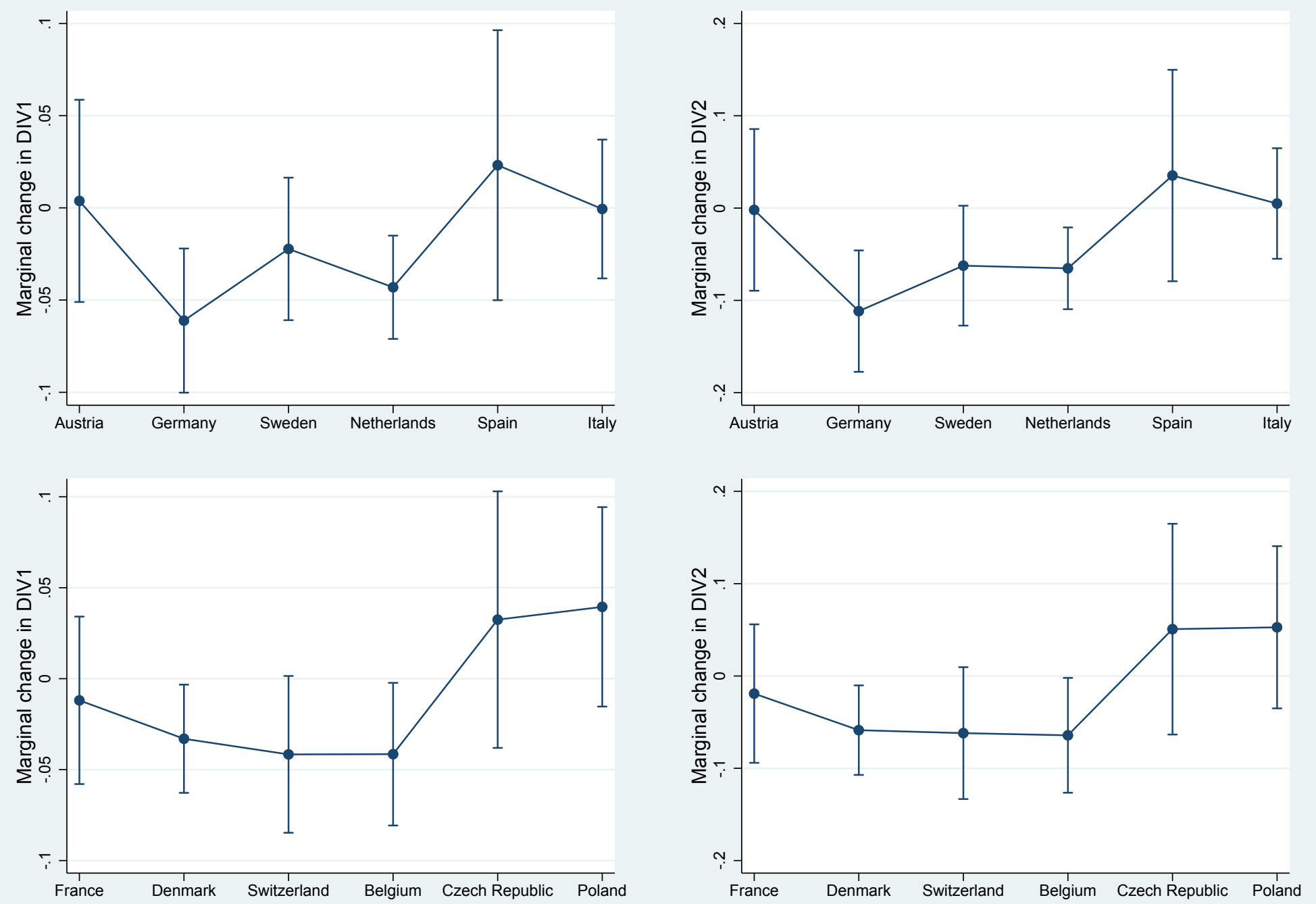
Figure 4: Marginal effect of GFC on portfolio diversity per occupation
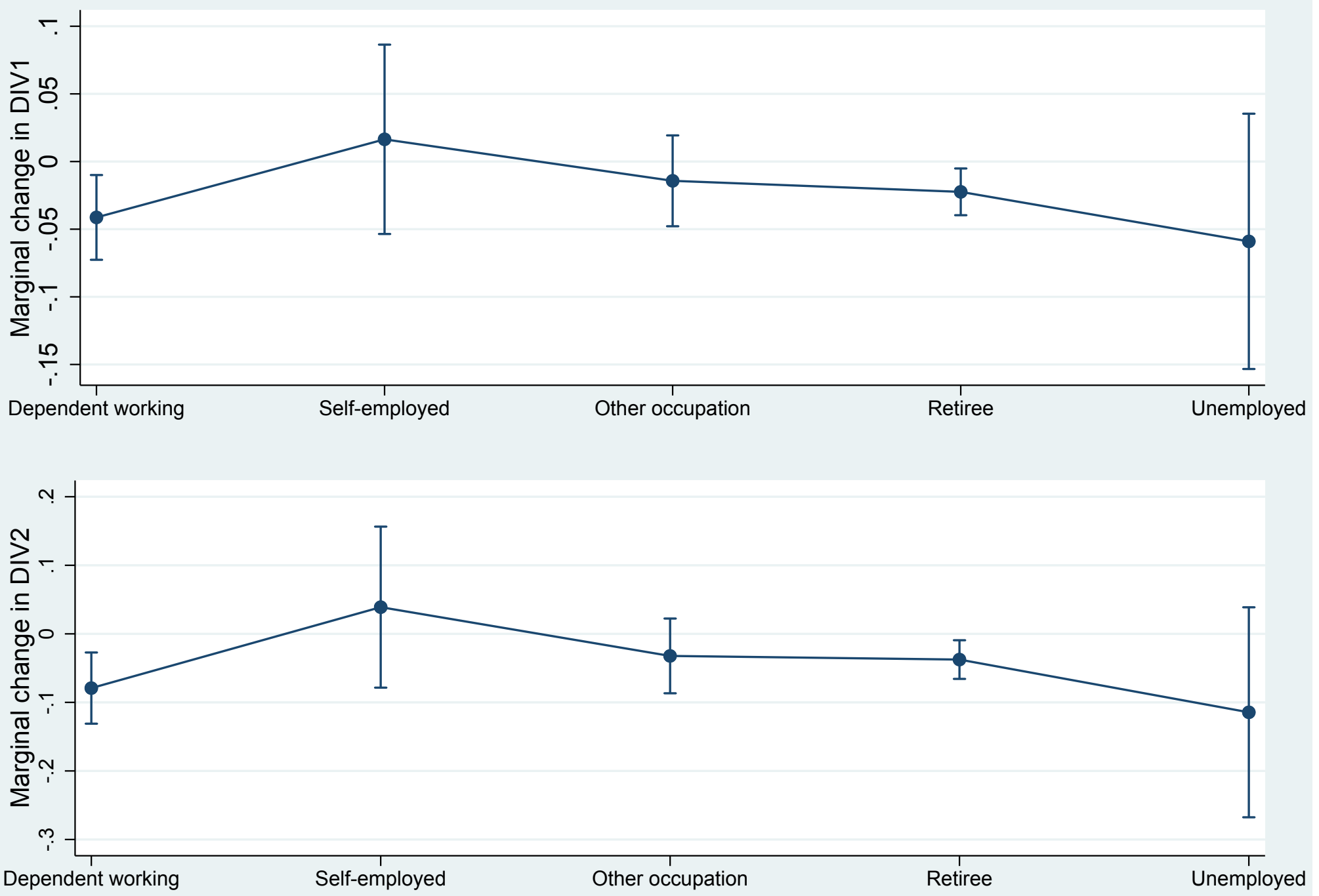
Table 1: Variable description

\begin{tabular}{|c|c|c|}
\hline Variable name & Description & Calibration \\
\hline $\begin{array}{l}\text { Crisis } \\
\text { post crisis }\end{array}$ & $\begin{array}{l}\text { Displays if observation is prior or post } \\
\text { Lehman insolvency }\end{array}$ & $\begin{array}{l}=1 \text { if date }=2011 / 2012 \\
=0 \text { if date }=2006 / 2007\end{array}$ \\
\hline $\begin{array}{l}\text { Individual charact } \\
\text { Time invariant } \\
\text { female }\end{array}$ & gender of individual & $=1$ if female, $=0$ if male \\
\hline risk group & self perceived risk aversion & $\begin{array}{l}=1 \text { if not any risk (base category) } \\
=2 \text { if average risk expecting average returns } \\
=3 \text { if above average risk expecting above aver- } \\
\text { age returns } \\
=4 \text { if substantial risk expecting substantial re- } \\
\text { turns }\end{array}$ \\
\hline $\begin{array}{l}\text { Time variant } \\
\text { age group }\end{array}$ & age & $\begin{array}{l}=1 \text { if age }<60.5 \text { (base category) } \\
=2 \text { if age }>=60.5 \& \text { age }<70.5 \\
=3 \text { if age }>=70.5\end{array}$ \\
\hline education group & level of education & $\begin{array}{l}=1 \text { if no education (base category) } \\
=2 \text { if less than high school } \\
=3 \text { if high school } \\
=4 \text { if some university studies } \\
=5 \text { if university degree } \\
=6 \text { if other education }\end{array}$ \\
\hline number of children & number of children & continuous, integer variable \\
\hline married & marital status & $=1$ married, $=0$ not married \\
\hline labor group & current job situation & $\begin{array}{l}=1 \text { if dependently working (base category) } \\
=2 \text { if self employed } \\
=3 \text { if other occupation } \\
=4 \text { if retiree, }=5 \text { if unemployed }\end{array}$ \\
\hline income group & Level of income & $\begin{array}{l}=1 \text { if income }<25000.5 \text { (base category) } \\
=2 \text { if income }>=25000.5 \& \text { income }<50000.5\end{array}$ \\
\hline
\end{tabular}


Table 1: Variable description

\begin{tabular}{|c|c|c|}
\hline Variable name & Description & Calibration \\
\hline & & $\begin{array}{l}=3 \text { if income }>=50000.5 \& \text { income }< \\
100000.5 \\
=4 \text { if income }>=100000.5\end{array}$ \\
\hline wealth class & division of wealth distribution per country in ten equal parts & wealth class $=1(($ base category $),=2,=3, \ldots=10$ \\
\hline home owner & in possession of a home & $=1$ if yes, $=0$ if no \\
\hline country & country the respondent lives in & Categorical variable \\
\hline \multicolumn{3}{|l|}{ Life events } \\
\hline PF value change & indicating value changes of asset sums from $2006 / 2007$ to $2011 / 2012$ & $=1$ if value increase, $=0$ if otherwise \\
\hline got divorced & got divorced from period $2006 / 2007$ to $2011 / 2012$ & $=1$ if divorce, $=0$ if otherwise \\
\hline stopped working & switch from working to not working & $=1$ if stopped working, $=0$ if otherwise \\
\hline health worse & health became worse & $=1$ if health worsened, $=0$ if otherwise \\
\hline had children & respondent switched from childless to any number of children & $\begin{array}{l}=1 \text { if change from no child to any number of } \\
\text { children } \\
=0 \text { if childless or only number of children } \\
\text { changed }\end{array}$ \\
\hline
\end{tabular}


Table 2: Summary Statistics

\begin{tabular}{lrrrrrrrr}
\hline & \multicolumn{3}{c}{ Pre Lehman insolvency } & \multicolumn{3}{c}{ Post Lehman insolvency } \\
& Mean & \multicolumn{1}{c}{ sd } & min & max & Mean & \multicolumn{1}{c}{ sd } & min & \multicolumn{2}{c}{$\max$} \\
\hline female & 0.472 & 0.499 & 0.0 & 1.0 & 0.472 & 0.499 & 0.0 & 1.0 \\
age at interview & 64.836 & 9.017 & 42.3 & 92.8 & 69.098 & 9.032 & 46.9 & 96.6 \\
education group & 2.936 & 0.860 & 1.0 & 6.0 & 2.936 & 0.860 & 1.0 & 6.0 \\
number of children & 2.106 & 1.353 & 0.0 & 12.0 & 2.105 & 1.356 & 0.0 & 12.0 \\
married & 0.612 & 0.487 & 0.0 & 1.0 & 0.566 & 0.496 & 0.0 & 1.0 \\
labor group & 3.007 & 1.335 & 1.0 & 5.0 & 3.310 & 1.177 & 1.0 & 5.0 \\
risk group & 1.458 & 0.716 & 1.0 & 4.0 & 1.458 & 0.716 & 1.0 & 4.0 \\
income group & 1.743 & 0.864 & 1.0 & 4.0 & 1.750 & 0.875 & 1.0 & 4.0 \\
wealth decile & 5.465 & 2.887 & 1.0 & 10.0 & 5.472 & 2.883 & 1.0 & 10.0 \\
\hline Observations & 2413 & & & & 2413 & & & \\
\hline
\end{tabular}

Note: The Table shows summary statistics of the used socio-demographic variables. The explanation of variables is in Table 1

Table 3: Value share of each asset type in percent

\begin{tabular}{llll}
\hline Type of asset & Pre & Post & Difference \\
\hline safe assets & 0.9993 & 0.9941 & $-0.0052 * * *$ \\
bank account & 0.9993 & 0.9941 & $-0.0052 * * *$ \\
fairly safe assets & 0.0003 & 0.0019 & $0.0016 * * *$ \\
bonds & 0.0001 & 0.0010 & $0.0009 * * *$ \\
savings for housing & 0.00007 & 0.00013 & $0.00006 * * *$ \\
whole life policy & 0.0001 & 0.0008 & $0.0007 * * *$ \\
risky assets & 0.0004 & 0.0040 & $0.0036 * * *$ \\
stocks & 0.0002 & 0.0019 & $0.0017 * * *$ \\
mutual funds & 0.0001 & 0.0012 & $0.0011 * * *$ \\
retirement accounts & 0.0001 & 0.0008 & $0.0008 * * *$ \\
\hline \hline
\end{tabular}

Note: All Assets account for 100 percent. The asset type bank account includes transaction accounts, saving accounts or postal accounts. savings for housing contains the amount of contractual savings for housing. The shares are calculated per wave by dividing the sum of asset value per asset type by the the value of all assets pre and post the Lehman insolvency. The time periods are pre Lehman insolvency (2006/2007) and post Lehman insolvency (2011/2012). The difference is tested by comparing the equality of given proportions. 
Table 4: Changes in ownership rates of financial assets

\begin{tabular}{lllc}
\hline & Pre & Post & Difference \\
\hline safe assets & 0.9341 & 0.9577 & $0.0236^{* * *}$ \\
bank account & 0.9341 & 0.9577 & $0.0236^{* * *}$ \\
fairly safe assets & 0.3336 & 0.2739 & $-0.0597^{* * *}$ \\
bonds & 0.1243 & 0.1090 & $-0.0153^{*}$ \\
savings for housing & 0.1169 & 0.0924 & $-0.0245^{* * *}$ \\
whole life policy & 0.1392 & 0.1078 & $-0.0315^{* * *}$ \\
risky assets & 0.4496 & 0.4111 & $-0.0385^{* * *}$ \\
stocks & 0.2482 & 0.2230 & $-0.0253^{* *}$ \\
mutual funds & 0.1919 & 0.1558 & $-0.0361^{* * *}$ \\
retirement accounts & 0.2176 & 0.1886 & $-0.0290^{* *}$ \\
\hline \hline
\end{tabular}

Table 5: Portfolio diversity per country

\begin{tabular}{lllll|llll|cc}
\hline & \multicolumn{3}{c|}{ Pre Lehman insolvency } & \multicolumn{3}{c|}{ Post Lehman insolvency } & \multicolumn{3}{c}{ Difference } \\
& DIV1 & DIV1 & DIV2 & DIV2 & DIV1 & DIV1 & DIV2 & DIV2 & DIV1 & DIV2 \\
Country & Detail & Cat. & Detail & Cat. & Detail & Cat. & Detail & Cat. & Detail & Detail \\
\hline Austria & .240 & .200 & .394 & .315 & .257 & .218 & .414 & .340 & .017 & .020 \\
Germany & .259 & .213 & .441 & .345 & .198 & .173 & .328 & .273 & $-.061^{* * *}$ & $-.113^{* * *}$ \\
Sweden & .366 & .258 & .631 & .416 & .327 & .265 & .542 & .414 & $-.038^{* *}$ & $-.089^{* * *}$ \\
Netherlands & .145 & .136 & .232 & .212 & .109 & .101 & .175 & .159 & $-.036^{* *}$ & $-.057^{* *}$ \\
Spain & .054 & .052 & .084 & .079 & .069 & .066 & .107 & .097 & .015 & .023 \\
Italy & .106 & .099 & .167 & .154 & .102 & .099 & .166 & .157 & -.005 & -.001 \\
France & .231 & .202 & .379 & .319 & .216 & .190 & .356 & .300 & -.015 & -.022 \\
Denmark & .272 & .232 & .454 & .369 & .229 & .197 & .378 & .313 & $-.043^{* * *}$ & $-.077^{* * *}$ \\
Switzerland & .271 & .246 & .449 & .389 & .238 & .212 & .398 & .337 & -.033 & -.051 \\
Belgium & .181 & .168 & .289 & .258 & .152 & .142 & .249 & .224 & -.029 & -.040 \\
Czech Republic & .250 & .237 & .405 & .376 & .257 & .251 & .413 & .400 & .007 & .008 \\
Poland & .066 & .061 & .110 & .098 & .099 & .099 & .151 & .150 & .034 & .041 \\
\hline Total sample & .227 & .192 & .377 & .304 & .199 & .175 & .327 & .276 & $-0.28^{* * *}$ & $-0.050^{* * *}$ \\
\hline \hline
\end{tabular}

Note: The values are rounded to three digits and based on the balanced panel (wave 2, prior to Lehman insolvency = 2,413 and wave 4, post to Lehman insolvency $=2,413$ observation. The table shows mean statistics of two measures of individual asset holdings: DIV1 calibrated in Equation (1) and DIV2 calibrated in Equation (2) indicate the level of portfolio diversity. Column Detail, describes the portfolio diversity with respect to the seven different asset categories, and column Cat. represents the diversity with respect to the three asset categories in the portfolio: Safe assets (Amount bank account), Fairly safe Assets (Amount in bonds, Face value of whole life policies, Amount contractual saving for housing), Risky Assets (Amount in stocks, Amount in mutual funds, Amount individual retirement accounts). With a t-test we estimate the significance of mean diversity differences. Highest diversification value for seven asset categories are a DIV1 (Gini-Simpson) equal to 0.85714 and DIV2 (Shannon-Entropy) equal to 1.94591 for detailed diversity measurement. 
Table 6: Great Financial Crisis and Portfolio Diversity - Basic Model

\begin{tabular}{|c|c|c|c|c|c|c|}
\hline & $\begin{array}{c}(1) \\
\text { DIV1 }\end{array}$ & $\begin{array}{c}(2) \\
\text { DIV2 }\end{array}$ & $\begin{array}{c}(3) \\
\text { DIV1 }\end{array}$ & $\begin{array}{c}\text { (4) } \\
\text { DIV2 }\end{array}$ & $\begin{array}{c}(5) \\
\text { DIV1 }\end{array}$ & $\begin{array}{c}(6) \\
\text { DIV2 }\end{array}$ \\
\hline post crisis & $\begin{array}{l}-0.0241^{* * *} \\
(-3.99)\end{array}$ & $\begin{array}{l}-0.0434^{* * *} \\
(-4.39)\end{array}$ & $\begin{array}{l}-0.0248^{* * *} \\
(-4.21)\end{array}$ & $\begin{array}{l}-0.0447^{* * *} \\
(-4.64)\end{array}$ & $\begin{array}{l}-0.0250^{* * *} \\
(-4.24)\end{array}$ & $\begin{array}{l}-0.0449^{* * *} \\
(-4.67)\end{array}$ \\
\hline female & $\begin{array}{l}-0.00615 \\
(-0.93)\end{array}$ & $\begin{array}{l}-0.0134 \\
(-1.24)\end{array}$ & $\begin{array}{l}-0.00388 \\
(-0.60)\end{array}$ & $\begin{array}{l}-0.00931 \\
(-0.89)\end{array}$ & $\begin{array}{l}-0.00504 \\
(-0.78)\end{array}$ & $\begin{array}{l}-0.0115 \\
(-1.09)\end{array}$ \\
\hline $60.6 \leq$ age $<70.5$ & $\begin{array}{l}-0.000251 \\
(-0.03)\end{array}$ & $\begin{array}{l}-0.00169 \\
(-0.11)\end{array}$ & $\begin{array}{l}-0.00494 \\
(-0.56)\end{array}$ & $\begin{array}{l}-0.00986 \\
(-0.68)\end{array}$ & $\begin{array}{l}-0.00546 \\
(-0.62)\end{array}$ & $\begin{array}{l}-0.0108 \\
(-0.74)\end{array}$ \\
\hline $70.5 \leq$ age & $\begin{array}{l}-0.0380^{* * *} \\
(-3.73)\end{array}$ & $\begin{array}{l}-0.0619^{* * *} \\
(-3.72)\end{array}$ & $\begin{array}{l}-0.0416^{* * *} \\
(-4.18)\end{array}$ & $\begin{array}{l}-0.0682^{* * *} \\
(-4.21)\end{array}$ & $\begin{array}{l}-0.0437^{* * *} \\
(-4.39)\end{array}$ & $\begin{array}{l}-0.0721^{* * *} \\
(-4.45)\end{array}$ \\
\hline less than high school & $\begin{array}{l}0.0499^{* * *} \\
(3.15)\end{array}$ & $\begin{array}{l}0.0756^{* * *} \\
(3.05)\end{array}$ & $\begin{array}{l}0.0402^{* *} \\
(2.41)\end{array}$ & $\begin{array}{l}0.0598^{* *} \\
(2.26)\end{array}$ & $\begin{array}{l}0.0399^{* *} \\
(2.38)\end{array}$ & $\begin{array}{l}0.0592^{* *} \\
(2.23)\end{array}$ \\
\hline high school & $\begin{array}{l}0.0841^{* * *} \\
(5.07)\end{array}$ & $\begin{array}{l}0.132^{* * *} \\
(5.07)\end{array}$ & $\begin{array}{l}0.0660^{* * *} \\
(3.78)\end{array}$ & $\begin{array}{l}0.101^{* * *} \\
(3.67)\end{array}$ & $\begin{array}{l}0.0642^{* * *} \\
(3.67)\end{array}$ & $\begin{array}{l}0.0982^{* * *} \\
(3.54)\end{array}$ \\
\hline some university studies & $\begin{array}{l}0.113^{* * *} \\
(6.54)\end{array}$ & $\begin{array}{l}0.181^{* * *} \\
(6.67)\end{array}$ & $\begin{array}{l}0.0835^{* * *} \\
(4.63)\end{array}$ & $\begin{array}{l}0.132^{* * *} \\
(4.59)\end{array}$ & $\begin{array}{l}0.0821^{* * *} \\
(4.55)\end{array}$ & $\begin{array}{l}0.129^{* * *} \\
(4.49)\end{array}$ \\
\hline university degree & $\begin{array}{l}0.0925^{*} \\
(1.73)\end{array}$ & $\begin{array}{l}0.145^{*} \\
(1.65)\end{array}$ & $\begin{array}{l}0.0749 \\
(1.53)\end{array}$ & $\begin{array}{l}0.114 \\
(1.42)\end{array}$ & $\begin{array}{l}0.0750 \\
(1.55)\end{array}$ & $\begin{array}{l}0.114 \\
(1.44)\end{array}$ \\
\hline other education & $\begin{array}{l}0.0221 \\
(0.68)\end{array}$ & $\begin{array}{l}0.0237 \\
(0.49)\end{array}$ & $\begin{array}{l}-0.00322 \\
(-0.10)\end{array}$ & $\begin{array}{l}-0.0183 \\
(-0.36)\end{array}$ & $\begin{array}{l}-0.00784 \\
(-0.24)\end{array}$ & $\begin{array}{l}-0.0269 \\
(-0.54)\end{array}$ \\
\hline number of children & $\begin{array}{l}-0.00580^{* * *} \\
(-2.81)\end{array}$ & $\begin{array}{l}-0.00865^{* *} \\
(-2.56)\end{array}$ & $\begin{array}{l}-0.00450^{* *} \\
(-2.22)\end{array}$ & $\begin{array}{l}-0.00641^{*} \\
(-1.94)\end{array}$ & $\begin{array}{l}-0.00433^{* *} \\
(-2.14)\end{array}$ & $\begin{array}{l}-0.00609^{*} \\
(-1.85)\end{array}$ \\
\hline married & $\begin{array}{l}0.0207^{* * *} \\
(2.95)\end{array}$ & $\begin{array}{l}0.0357^{* * *} \\
(3.11)\end{array}$ & $\begin{array}{l}0.00150 \\
(0.21)\end{array}$ & $\begin{array}{l}0.00280 \\
(0.24)\end{array}$ & $\begin{array}{l}0.00207 \\
(0.29)\end{array}$ & $\begin{array}{l}0.00386 \\
(0.34)\end{array}$ \\
\hline self-employed & $\begin{array}{l}0.0171 \\
(0.90)\end{array}$ & $\begin{array}{l}0.0278 \\
(0.88)\end{array}$ & $\begin{array}{l}-0.00880 \\
(-0.46)\end{array}$ & $\begin{array}{l}-0.0188 \\
(-0.58)\end{array}$ & $\begin{array}{l}-0.00939 \\
(-0.49)\end{array}$ & $\begin{array}{l}-0.0199 \\
(-0.62)\end{array}$ \\
\hline other occupation & $\begin{array}{l}-0.0248^{* *} \\
(-2.07)\end{array}$ & $\begin{array}{l}-0.0375^{*} \\
(-1.90)\end{array}$ & $\begin{array}{l}-0.0193^{*} \\
(-1.67)\end{array}$ & $\begin{array}{l}-0.0291 \\
(-1.54)\end{array}$ & $\begin{array}{l}-0.0191^{*} \\
(-1.66)\end{array}$ & $\begin{array}{l}-0.0287 \\
(-1.52)\end{array}$ \\
\hline retiree & $\begin{array}{l}-0.0239^{* *} \\
(-2.27)\end{array}$ & $\begin{array}{l}-0.0446^{* *} \\
(-2.54)\end{array}$ & $\begin{array}{l}-0.0266^{* * *} \\
(-2.60)\end{array}$ & $\begin{array}{l}-0.0494^{* * *} \\
(-2.91)\end{array}$ & $\begin{array}{l}-0.0264^{* * *} \\
(-2.59)\end{array}$ & $\begin{array}{l}-0.0491^{* * *} \\
(-2.89)\end{array}$ \\
\hline unemployed & $\begin{array}{l}0.00131 \\
(0.05)\end{array}$ & $\begin{array}{l}0.00437 \\
(0.10)\end{array}$ & $\begin{array}{l}0.0174 \\
(0.73)\end{array}$ & $\begin{array}{l}0.0309 \\
(0.79)\end{array}$ & $\begin{array}{l}0.0178 \\
(0.75)\end{array}$ & $\begin{array}{l}0.0317 \\
(0.81)\end{array}$ \\
\hline average risk & $\begin{array}{l}0.114^{* * *} \\
(13.72)\end{array}$ & $\begin{array}{l}0.201^{* * *} \\
(14.58)\end{array}$ & $\begin{array}{l}0.0972^{* * *} \\
(11.84)\end{array}$ & $\begin{array}{l}0.172^{* * *} \\
(12.67)\end{array}$ & $\begin{array}{l}0.0972^{* * *} \\
(11.86)\end{array}$ & $\begin{array}{l}0.172^{* * *} \\
(12.70)\end{array}$ \\
\hline above average risk & $\begin{array}{l}0.103^{* * *} \\
(7.93)\end{array}$ & $\begin{array}{l}0.187^{* * *} \\
(8.59)\end{array}$ & $\begin{array}{l}0.0838^{* * *} \\
(6.55)\end{array}$ & $\begin{array}{l}0.154^{* * *} \\
(7.17)\end{array}$ & $\begin{array}{l}0.0831^{* * *} \\
(6.49)\end{array}$ & $\begin{array}{l}0.153^{* * *} \\
(7.11)\end{array}$ \\
\hline substantial risk & $\begin{array}{l}0.149^{* * *} \\
(5.61)\end{array}$ & $\begin{array}{l}0.267^{* * *} \\
(5.90)\end{array}$ & $\begin{array}{l}0.143^{* * *} \\
(5.44)\end{array}$ & $\begin{array}{l}0.255^{* * *} \\
(5.75)\end{array}$ & $\begin{array}{l}0.142^{* * *} \\
(5.44)\end{array}$ & $\begin{array}{l}0.253^{* * *} \\
(5.75)\end{array}$ \\
\hline $25000.5 \leq$ income $<50000.5$ & $\begin{array}{l}0.0578^{* * *} \\
(7.47)\end{array}$ & $\begin{array}{l}0.0970^{* * *} \\
(7.70)\end{array}$ & $\begin{array}{l}0.0404^{* * *} \\
(5.28)\end{array}$ & $\begin{array}{l}0.0673^{* * *} \\
(5.42)\end{array}$ & $\begin{array}{l}0.0396^{* * *} \\
(5.17)\end{array}$ & $\begin{array}{l}0.0658^{* * *} \\
(5.30)\end{array}$ \\
\hline $50000.5 \leq$ income $<100000.5$ & $\begin{array}{l}0.0834^{* * *} \\
(7.86)\end{array}$ & $\begin{array}{l}0.149^{* * *} \\
(8.44)\end{array}$ & $\begin{array}{l}0.0565^{* * *} \\
(5.34)\end{array}$ & $\begin{array}{l}0.102^{* * *} \\
(5.80)\end{array}$ & $\begin{array}{l}0.0563^{* * *} \\
(5.33)\end{array}$ & $\begin{array}{l}0.102^{* * *} \\
(5.80)\end{array}$ \\
\hline $100000.5 \leq$ income & $\begin{array}{l}0.0848^{* * *} \\
(5.23)\end{array}$ & $\begin{array}{l}0.151^{* * *} \\
(5.52)\end{array}$ & $\begin{array}{l}0.0620^{* * *} \\
(3.94)\end{array}$ & $\begin{array}{l}0.111^{* * *} \\
(4.18)\end{array}$ & $\begin{array}{l}0.0625^{* * *} \\
(3.98)\end{array}$ & $\begin{array}{l}0.112^{* * *} \\
(4.23)\end{array}$ \\
\hline wealth decile $=2$ & & & $\begin{array}{l}0.0771^{* * *} \\
(7.05)\end{array}$ & $\begin{array}{l}0.122^{* * *} \\
(7.12)\end{array}$ & $\begin{array}{l}0.0796^{* * *} \\
(7.24)\end{array}$ & $\begin{array}{l}0.127^{* * *} \\
(7.35)\end{array}$ \\
\hline wealth decile $=3$ & & & $\begin{array}{l}0.0784^{* * *} \\
(7.27)\end{array}$ & $\begin{array}{l}0.124^{* * *} \\
(7.27)\end{array}$ & $\begin{array}{l}0.0942^{* * *} \\
(7.92)\end{array}$ & $\begin{array}{l}0.153^{* * *} \\
(8.10)\end{array}$ \\
\hline wealth decile $=4$ & & & $\begin{array}{l}0.0909^{* * *} \\
(8.02)\end{array}$ & $\begin{array}{l}0.147^{* * *} \\
(8.09)\end{array}$ & $\begin{array}{l}0.116^{* * *} \\
(8.37)\end{array}$ & $\begin{array}{l}0.193^{* * *} \\
(8.73)\end{array}$ \\
\hline wealth decile $=5$ & & & $\begin{array}{l}0.121^{* * *} \\
(10.15)\end{array}$ & $\begin{array}{l}0.198^{* * *} \\
(10.32)\end{array}$ & $\begin{array}{l}0.151^{\text {*** }} \\
(9.73)\end{array}$ & $\begin{array}{l}0.255^{* * *} \\
(10.11)\end{array}$ \\
\hline wealth decile $=6$ & & & $\begin{array}{l}0.139^{* * *} \\
(11.42)\end{array}$ & $\begin{array}{l}0.231^{* * *} \\
(11.70)\end{array}$ & $\begin{array}{l}0.172^{* * *} \\
(10.61)\end{array}$ & $\begin{array}{l}0.292^{* * *} \\
(11.11)\end{array}$ \\
\hline wealth decile $=7$ & & & $\begin{array}{l}0.127^{* * *} \\
(10.72)\end{array}$ & $\begin{array}{l}0.208^{* * *} \\
(10.87)\end{array}$ & $\begin{array}{l}0.162^{* * *} \\
(9.99)\end{array}$ & $\begin{array}{l}0.272^{* * *} \\
(10.40)\end{array}$ \\
\hline wealth decile $=8$ & & & $\begin{array}{l}0.152^{* * *} \\
(11.80)\end{array}$ & $\begin{array}{l}0.253^{* * *} \\
(12.06)\end{array}$ & $\begin{array}{l}0.186^{* * *} \\
(11.00)\end{array}$ & $\begin{array}{l}0.316^{* * *} \\
(11.49)\end{array}$ \\
\hline wealth decile $=9$ & & & $0.168^{* * *}$ & $0.282^{* * *}$ & $0.202^{* * *}$ & $0.346^{* * *}$ \\
\hline
\end{tabular}


wealth decile $=10$

(13.05)

(13.24)

(11.96)

(12.45)

$0.181^{* * *}$

$0.311^{* * *}$

$0.215^{* * *}$

$0.375^{\text {*** }}$

home owner

(13.68)

(14.09)

(12.51)

(13.21)

Constant

$0.174^{* * *}$

$0.289^{* * *}$

$0.100^{* * *}$

$0.168^{* * *}$

$(-3.19)$

$-0.0689^{* *}$

\section{Observations}

(7.15)

(7.41)

(3.99)

(4.18)

$0.0961^{* * *}$

$(-3.68)$

4826

4826

4826

4826

(3.84)

$t$ statistics in parentheses, ${ }^{*} p<0.10,{ }^{* *} p<0.05,{ }^{* * *} p<0.01 .$.

4826

Note: We apply regression Equation (3) to estimate the effect of socio-demographic, time-independent and time-dependent household characteristics as well as of country-level variables on DIV1 (Gini-Simpson Index, Equation (1)) and DIV2 (Shannon-Entropy Index, Equation (2)). The OLS regression uses a balanced panel with pooled data across both waves. Standard errors are robust. The base categories are age $<60.5$, no education, dependently working, not any risk, income $<25000.5$ and wealth decile $=1$. Country dummy variables are included in each specification. 
Table 7: Change in portfolio diversity: Life events and change of financial wealth

\begin{tabular}{|c|c|c|c|c|c|c|}
\hline & $\begin{array}{c}(1) \\
\text { Prob } \\
(\Delta \mathrm{DIV} 1 \\
>0)\end{array}$ & $\begin{array}{c}(2) \\
\text { Prob } \\
(\Delta \mathrm{DIV} 2 \\
>0)\end{array}$ & $\begin{array}{c}(3) \\
\text { Prob } \\
(\Delta \mathrm{DIV} 1 \\
>0)\end{array}$ & $\begin{array}{c}(4) \\
\text { Prob } \\
(\Delta \mathrm{DIV} 2 \\
>0)\end{array}$ & $\begin{array}{c}(5) \\
\text { Prob } \\
(\Delta \mathrm{DIV} 1 \\
>0)\end{array}$ & $\begin{array}{c}(6) \\
\text { Prob } \\
(\Delta \mathrm{DIV} 2 \\
>0)\end{array}$ \\
\hline PF value change & $\begin{array}{l}0.778^{* * *} \\
(7.82)\end{array}$ & $\begin{array}{l}0.843^{* * *} \\
(8.35)\end{array}$ & $\begin{array}{l}0.746^{* * *} \\
(7.36)\end{array}$ & $\begin{array}{l}0.813^{* * *} \\
(7.92)\end{array}$ & $\begin{array}{l}0.734^{* * *} \\
(7.28)\end{array}$ & $\begin{array}{l}0.802^{* * *} \\
(7.84)\end{array}$ \\
\hline got divorced & $\begin{array}{l}-0.179 \\
(-0.72)\end{array}$ & $\begin{array}{l}-0.250 \\
(-1.00)\end{array}$ & $\begin{array}{c}-0.174 \\
(-0.69)\end{array}$ & $\begin{array}{l}-0.245 \\
(-0.95)\end{array}$ & $\begin{array}{l}-0.161 \\
(-0.64)\end{array}$ & $\begin{array}{l}-0.232 \\
(-0.91)\end{array}$ \\
\hline stopped working & $\begin{array}{l}0.0124 \\
(0.09)\end{array}$ & $\begin{array}{l}-0.131 \\
(-0.92)\end{array}$ & $\begin{array}{l}-0.0140 \\
(-0.10)\end{array}$ & $\begin{array}{l}-0.155 \\
(-1.07)\end{array}$ & $\begin{array}{l}-0.00306 \\
(-0.02)\end{array}$ & $\begin{array}{l}-0.145 \\
(-1.00)\end{array}$ \\
\hline health became worse & $\begin{array}{l}-0.0540 \\
(-0.51)\end{array}$ & $\begin{array}{l}-0.0752 \\
(-0.71)\end{array}$ & $\begin{array}{l}-0.0377 \\
(-0.36)\end{array}$ & $\begin{array}{l}-0.0629 \\
(-0.59)\end{array}$ & $\begin{array}{l}-0.0390 \\
(-0.37)\end{array}$ & $\begin{array}{l}-0.0649 \\
(-0.61)\end{array}$ \\
\hline had children & $\begin{array}{l}-0.0777 \\
(-0.14)\end{array}$ & $\begin{array}{l}-0.0513 \\
(-0.10)\end{array}$ & $\begin{array}{l}0.0401 \\
(0.07)\end{array}$ & $\begin{array}{l}0.0600 \\
(0.10)\end{array}$ & $\begin{array}{l}0.0384 \\
(0.06)\end{array}$ & $\begin{array}{l}0.0565 \\
(0.09)\end{array}$ \\
\hline average risk & $\begin{array}{l}0.266^{* *} \\
(2.21)\end{array}$ & $\begin{array}{l}0.276^{* *} \\
(2.26)\end{array}$ & $\begin{array}{l}0.213^{*} \\
(1.76)\end{array}$ & $\begin{array}{l}0.229^{*} \\
(1.87)\end{array}$ & & \\
\hline above average risk & $\begin{array}{l}0.155 \\
(0.81)\end{array}$ & $\begin{array}{l}0.102 \\
(0.53)\end{array}$ & $\begin{array}{l}0.0732 \\
(0.38)\end{array}$ & $\begin{array}{l}0.0278 \\
(0.14)\end{array}$ & & \\
\hline substantial risk & $\begin{array}{l}0.413 \\
(1.03)\end{array}$ & $\begin{array}{l}0.220 \\
(0.52)\end{array}$ & $\begin{array}{l}0.359 \\
(0.87)\end{array}$ & $\begin{array}{l}0.164 \\
(0.37)\end{array}$ & & \\
\hline demographic controls & Yes & Yes & Yes & Yes & Yes & Yes \\
\hline income controls & Yes & Yes & Yes & Yes & Yes & Yes \\
\hline wealth controls & No & No & Yes & Yes & Yes & Yes \\
\hline Observations & 2413 & 2413 & 2413 & 2413 & 2413 & 2413 \\
\hline
\end{tabular}

$t$ statistics in parentheses, ${ }^{*} p<0.10,{ }^{* *} p<0.05,{ }^{* * *} p<0.01$.

Note: The Table reports the coefficients of the logit estimation defined in regression Equation (4) based on crosssectional data representing the impact of life events and financial wealth changes during the crisis on portfolio diversity. The coefficients are odds-ratios. Diversity is represented by DIV1 (Gini-Simpson Index, Equation (1)) and DIV2 (Shannon-Entropy Index, Equation 2)). The dependent variable is 1 if the diversity indicators increase and zero if the indicators decrease or remain constant. The life events are dummy variables with value one, and zero otherwise, if the head of household experienced a portfolio value change, got divorced, stopped working, suffers from deteriorating health, or switched from having no children to having children. The base categorie for risk group is not any risk. Control variables are demographic characteristics (female, age, education group), the income group and the wealth deciles. Respective countries are considered in the form of country dummies. 
Table 8: CRE panel estimation - GFC and Diversity (balanced panel)

\begin{tabular}{|c|c|c|}
\hline & $\begin{array}{l}\text { DIV1 } \\
\text { (1) }\end{array}$ & $\begin{array}{l}\text { DIV2 } \\
\text { (2) }\end{array}$ \\
\hline post crisis & $\begin{array}{c}-0.0226^{* * *} \\
(-4.49)\end{array}$ & $\begin{array}{c}-0.0405^{* * *} \\
(-5.06)\end{array}$ \\
\hline female & $\begin{array}{c}-0.00408 \\
(-0.53)\end{array}$ & $\begin{array}{c}-0.00985 \\
(-0.78)\end{array}$ \\
\hline \multicolumn{3}{|l|}{ age group } \\
\hline $60.5 \leq$ age $<70.5$ & $\begin{array}{c}-0.00840 \\
(-0.77)\end{array}$ & $\begin{array}{c}-0.0169 \\
(-0.94)\end{array}$ \\
\hline $70.5 \leq$ age & $\begin{array}{c}-0.0466^{* * *} \\
(-3.68)\end{array}$ & $\begin{array}{c}-0.0783^{* * *} \\
(-3.74)\end{array}$ \\
\hline \multicolumn{3}{|l|}{ education group } \\
\hline less than high school & $\begin{array}{c}0.0363 \\
(1.25)\end{array}$ & $\begin{array}{c}0.0533 \\
(1.11)\end{array}$ \\
\hline high school & $\begin{array}{c}0.0586^{* *} \\
(1.99)\end{array}$ & $\begin{array}{c}0.0892^{*} \\
(1.83)\end{array}$ \\
\hline some university studies & $\begin{array}{c}0.0747^{* *} \\
(2.50)\end{array}$ & $\begin{array}{c}0.117^{* *} \\
(2.37)\end{array}$ \\
\hline university degree & $\begin{array}{c}0.0703 \\
(1.13)\end{array}$ & $\begin{array}{l}0.105 \\
(1.02)\end{array}$ \\
\hline other education & $\begin{array}{c}-0.0153 \\
(-0.32)\end{array}$ & $\begin{array}{c}-0.0391 \\
(-0.49)\end{array}$ \\
\hline number of children & $\begin{array}{c}0.0197^{* *} \\
(2.05)\end{array}$ & $\begin{array}{c}0.0331^{* *} \\
(2.16)\end{array}$ \\
\hline married & $\begin{array}{l}0.0153 \\
(0.72)\end{array}$ & $\begin{array}{l}0.0234 \\
(0.70)\end{array}$ \\
\hline \multicolumn{3}{|l|}{ labour group } \\
\hline self-employed & $\begin{array}{c}0.00208 \\
(0.06)\end{array}$ & $\begin{array}{c}0.00327 \\
(0.06)\end{array}$ \\
\hline other occupation & $\begin{array}{c}-0.0467^{* *} \\
(-2.34)\end{array}$ & $\begin{array}{c}-0.0779^{* *} \\
(-2.45)\end{array}$ \\
\hline retiree & $\begin{array}{c}-0.0408^{* * *} \\
(-2.76)\end{array}$ & $\begin{array}{c}-0.0770^{* * *} \\
(-3.27)\end{array}$ \\
\hline unemployed & $\begin{array}{l}0.0136 \\
(0.48)\end{array}$ & $\begin{array}{c}0.0298 \\
(0.65)\end{array}$ \\
\hline \multicolumn{3}{|l|}{ risk group } \\
\hline average risk & $\begin{array}{c}0.0948^{* * *} \\
(10.77)\end{array}$ & $\begin{array}{c}0.168^{* * *} \\
(11.55)\end{array}$ \\
\hline above average risk & $\begin{array}{c}0.0806^{* * *} \\
(6.02)\end{array}$ & $\begin{array}{c}0.148^{* * *} \\
(6.71)\end{array}$ \\
\hline substantial risk & $\begin{array}{c}0.137^{* * *} \\
(4.66)\end{array}$ & $\begin{array}{c}0.246^{* * *} \\
(5.05)\end{array}$ \\
\hline \multicolumn{3}{|l|}{ income group } \\
\hline $25000.5 \leq$ income $<50000.5$ & $\begin{array}{c}0.0183^{*} \\
(1.82)\end{array}$ & $\begin{array}{c}0.0310^{*} \\
(1.93)\end{array}$ \\
\hline $50000.5 \leq$ income $<100000.5$ & $\begin{array}{c}0.0189 \\
(1.41)\end{array}$ & $\begin{array}{c}0.0363^{*} \\
(1.69)\end{array}$ \\
\hline $100000.5 \leq$ income & $\begin{array}{c}-0.00488 \\
(-0.24)\end{array}$ & $\begin{array}{c}0.00749 \\
(0.23)\end{array}$ \\
\hline \multicolumn{3}{|l|}{ wealth class } \\
\hline wealth decile $=2$ & $\begin{array}{c}0.0560^{* * *} \\
(3.18)\end{array}$ & $\begin{array}{c}0.0886^{* * *} \\
(3.16)\end{array}$ \\
\hline wealth decile $=3$ & $\begin{array}{c}0.0775^{* * *} \\
(3.74)\end{array}$ & $\begin{array}{c}0.130^{* * *} \\
(3.94)\end{array}$ \\
\hline wealth decile $=4$ & $\begin{array}{c}0.0793^{* * *} \\
(3.40)\end{array}$ & $\begin{array}{c}0.143^{* * *} \\
(3.84)\end{array}$ \\
\hline wealth decile $=5$ & $\begin{array}{c}0.0880^{* * * *} \\
(3.52)\end{array}$ & $\begin{array}{c}0.159^{* * *} \\
(4.00)\end{array}$ \\
\hline
\end{tabular}


Table 8: CRE panel estimation - GFC and Diversity (balanced panel)

\begin{tabular}{|c|c|c|}
\hline & $\begin{array}{l}\text { DIV1 } \\
(1)\end{array}$ & $\begin{array}{l}\text { DIV2 } \\
\text { (2) }\end{array}$ \\
\hline wealth decile $=6$ & $\begin{array}{c}0.117^{* * *} \\
(4.49)\end{array}$ & $\begin{array}{c}0.207^{* * *} \\
(4.98)\end{array}$ \\
\hline wealth decile $=7$ & $\begin{array}{c}0.0772^{* * *} \\
(2.89)\end{array}$ & $\begin{array}{c}0.142^{* * *} \\
(3.34)\end{array}$ \\
\hline wealth decile $=8$ & $\begin{array}{c}0.0902^{* * *} \\
(3.30)\end{array}$ & $\begin{array}{c}0.167^{* * *} \\
(3.82)\end{array}$ \\
\hline wealth decile $=9$ & $\begin{array}{c}0.116^{* * *} \\
(4.06)\end{array}$ & $\begin{array}{c}0.207^{* * *} \\
(4.53)\end{array}$ \\
\hline wealth decile $=10$ & $\begin{array}{c}0.162^{* * *} \\
(5.39)\end{array}$ & $\begin{array}{c}0.282^{* * *} \\
(5.87)\end{array}$ \\
\hline home owner & $\begin{array}{c}-0.0304 \\
(-1.21)\end{array}$ & $\begin{array}{c}-0.0602 \\
(-1.50)\end{array}$ \\
\hline group means & & \\
\hline number of children & $\begin{array}{c}-0.0247^{* *} \\
(-2.48)\end{array}$ & $\begin{array}{c}-0.0403^{* *} \\
(-2.53)\end{array}$ \\
\hline married & $\begin{array}{c}-0.0205 \\
(-0.90)\end{array}$ & $\begin{array}{c}-0.0316 \\
(-0.86)\end{array}$ \\
\hline home owner & $\begin{array}{c}-0.0163 \\
(-0.56)\end{array}$ & $\begin{array}{c}-0.0233 \\
(-0.50)\end{array}$ \\
\hline labor group $=2$ & $\begin{array}{c}-0.00705 \\
(-0.17)\end{array}$ & $\begin{array}{c}-0.0179 \\
(-0.27)\end{array}$ \\
\hline labor group $=3$ & $\begin{array}{c}0.0399 \\
(1.57)\end{array}$ & $\begin{array}{c}0.0708^{*} \\
(1.72)\end{array}$ \\
\hline labor group $=4$ & $\begin{array}{l}0.0229 \\
(1.14)\end{array}$ & $\begin{array}{c}0.0439 \\
(1.34)\end{array}$ \\
\hline labor group $=5$ & $\begin{array}{l}0.0117 \\
(0.27)\end{array}$ & $\begin{array}{l}0.0106 \\
(0.15)\end{array}$ \\
\hline income group $=2$ & $\begin{array}{c}0.0312^{* *} \\
(2.08)\end{array}$ & $\begin{array}{c}0.0512^{* *} \\
(2.10)\end{array}$ \\
\hline income group $=3$ & $\begin{array}{c}0.0571^{* * *} \\
(2.82)\end{array}$ & $\begin{array}{c}0.101^{* * *} \\
(3.05)\end{array}$ \\
\hline income group $=4$ & $\begin{array}{c}0.106^{* * *} \\
(3.47)\end{array}$ & $\begin{array}{c}0.162^{* * *} \\
(3.26)\end{array}$ \\
\hline wealth decile $=2$ & $\begin{array}{c}0.0356 \\
(1.38)\end{array}$ & $\begin{array}{l}0.0583 \\
(1.39)\end{array}$ \\
\hline wealth decile $=3$ & $\begin{array}{l}0.0217 \\
(0.77)\end{array}$ & $\begin{array}{l}0.0304 \\
(0.66)\end{array}$ \\
\hline wealth decile $=4$ & $\begin{array}{c}0.0489 \\
(1.57)\end{array}$ & $\begin{array}{c}0.0674 \\
(1.34)\end{array}$ \\
\hline wealth decile $=5$ & $\begin{array}{c}0.0871^{* * *} \\
(2.59)\end{array}$ & $\begin{array}{c}0.132^{* *} \\
(2.43)\end{array}$ \\
\hline wealth decile $=6$ & $\begin{array}{c}0.0613^{*} \\
(1.78)\end{array}$ & $\begin{array}{c}0.0960^{*} \\
(1.71)\end{array}$ \\
\hline wealth decile $=7$ & $\begin{array}{c}0.112^{* * *} \\
(3.18)\end{array}$ & $\begin{array}{c}0.172^{* * *} \\
(3.00)\end{array}$ \\
\hline wealth decile $=8$ & $\begin{array}{c}0.122^{* * *} \\
(3.41)\end{array}$ & $\begin{array}{c}0.190^{* * *} \\
(3.27)\end{array}$ \\
\hline wealth decile $=9$ & $\begin{array}{c}0.106^{* * *} \\
(2.87)\end{array}$ & $\begin{array}{c}0.170^{* * *} \\
(2.85)\end{array}$ \\
\hline wealth decile $=10$ & $\begin{array}{c}0.0606 \\
(1.60)\end{array}$ & $\begin{array}{c}0.107^{*} \\
(1.75)\end{array}$ \\
\hline Constant & $\begin{array}{c}0.0834^{* *} \\
(2.26)\end{array}$ & $\begin{array}{c}0.140^{* *} \\
(2.28)\end{array}$ \\
\hline Observations & 4826 & 4826 \\
\hline
\end{tabular}


Table 8: CRE panel estimation - GFC and Diversity (balanced panel)

$$
\begin{array}{cc}
\text { DIV1 } & \text { DIV2 } \\
(1) & (2)
\end{array}
$$

Note: The Table shows the CRE estimations for post crisis and the other covariates. The base categories are age $<60.5$, no education, dependently working, not any risk, income $<25000.5$, wealth decile $=1$. Country dummies included. Standard errors are in pharanteses, significance levels: ${ }^{*} p<0.1,{ }^{* *} p<0.05$, ${ }^{* * *} p<0.01$. The estimation applies the Perales' mundlak command (Perales, 2013). The joint test of the mean coefficients strongly rejects the null hypothesis that those coefficients are jointly zero. This indicates that the pure RE model is not appropriate, and that the CRE model should be used.

\begin{tabular}{|c|c|c|}
\hline & $\begin{array}{l}\text { Marginal effects } \\
\text { DIV1 }\end{array}$ & $\begin{array}{l}\text { Marginal effects } \\
\text { DIV2 }\end{array}$ \\
\hline post crisis & $\begin{array}{l}-0.0253^{* * *} \\
(-4.29)\end{array}$ & $\begin{array}{l}-0.0456^{* * *} \\
(-4.74)\end{array}$ \\
\hline female & $\begin{array}{l}-0.00521 \\
(-0.81)\end{array}$ & $\begin{array}{l}-0.0119 \\
(-1.12)\end{array}$ \\
\hline $60.5 \leq$ age $<70.5$ & $\begin{array}{l}-0.00625 \\
(-0.70)\end{array}$ & $\begin{array}{l}-0.0127 \\
(-0.87)\end{array}$ \\
\hline $70.5 \leq$ age & $\begin{array}{l}-0.0448^{* * *} \\
(-4.48)\end{array}$ & $\begin{array}{l}-0.0744^{* * *} \\
(-4.55)\end{array}$ \\
\hline less than highschool & $\begin{array}{l}0.0417^{* *} \\
(2.48)\end{array}$ & $\begin{array}{l}0.0622^{* *} \\
(2.34)\end{array}$ \\
\hline highschool & $\begin{array}{l}0.0657^{* * *} \\
(3.73)\end{array}$ & $\begin{array}{l}0.101^{* * *} \\
(3.62)\end{array}$ \\
\hline some university studies & $\begin{array}{l}0.0833^{* * *} \\
(4.59)\end{array}$ & $\begin{array}{l}0.131^{* * *} \\
(4.55)\end{array}$ \\
\hline university degree & $\begin{array}{l}0.0772 \\
(1.55)\end{array}$ & $\begin{array}{l}0.118 \\
(1.45)\end{array}$ \\
\hline other education & $\begin{array}{l}-0.00818 \\
(-0.24)\end{array}$ & $\begin{array}{l}-0.0264 \\
(-0.52)\end{array}$ \\
\hline number of children & $\begin{array}{l}-0.00437^{* *} \\
(-2.15)\end{array}$ & $\begin{array}{l}-0.00614^{*} \\
(-1.85)\end{array}$ \\
\hline married & $\begin{array}{l}0.00229 \\
(0.33)\end{array}$ & $\begin{array}{l}0.00431 \\
(0.37)\end{array}$ \\
\hline selfemployed & $\begin{array}{l}-0.00814 \\
(-0.43)\end{array}$ & $\begin{array}{l}-0.0161 \\
(-0.50)\end{array}$ \\
\hline other occupation & $\begin{array}{l}-0.0169 \\
(-1.45)\end{array}$ & $\begin{array}{l}-0.0240 \\
(-1.26)\end{array}$ \\
\hline retiree & $\begin{array}{l}-0.0237^{* *} \\
(-2.30)\end{array}$ & $\begin{array}{l}-0.0434^{* *} \\
(-2.54)\end{array}$ \\
\hline unemployed & $\begin{array}{l}0.0108 \\
(0.44)\end{array}$ & $\begin{array}{l}0.0204 \\
(0.51)\end{array}$ \\
\hline average risk & $\begin{array}{l}0.0972^{* * *} \\
(11.84)\end{array}$ & $\begin{array}{l}0.172^{* * *} \\
(12.68)\end{array}$ \\
\hline above average risk & $\begin{array}{l}0.0836^{* * *} \\
(6.52)\end{array}$ & $\begin{array}{l}0.153^{* * *} \\
(7.14)\end{array}$ \\
\hline substantial risk & $\begin{array}{l}0.140^{* * *} \\
(5.39)\end{array}$ & $\begin{array}{l}0.252^{* * *} \\
(5.71)\end{array}$ \\
\hline $25000.5 \leq$ income $<50000.5$ & $\begin{array}{l}0.0394^{* * *} \\
(5.14)\end{array}$ & $\begin{array}{l}0.0654^{* * *} \\
(5.25)\end{array}$ \\
\hline $50000.5 \leq$ income $<100000.5$ & $\begin{array}{l}0.0562^{* * *} \\
(5.29)\end{array}$ & $\begin{array}{l}0.101^{* * *} \\
(5.76)\end{array}$ \\
\hline $100000.5 \leq$ income & $\begin{array}{l}0.0625^{* * *} \\
(3.96)\end{array}$ & $\begin{array}{l}0.111^{* * *} \\
(4.18)\end{array}$ \\
\hline wealth decile $=2$ & $\begin{array}{l}0.0791^{* * *} \\
(7.20)\end{array}$ & $\begin{array}{l}0.126^{* * *} \\
(7.32)\end{array}$ \\
\hline
\end{tabular}

Table 9: Robustness check - Marginal effects GFC and Diversity 
Table 9: Robustness - GFC and Diversity

\begin{tabular}{|c|c|c|}
\hline & $\begin{array}{l}\text { Marginal effects } \\
\text { DIV1 }\end{array}$ & $\begin{array}{l}\text { Marginal effects } \\
\text { DIV2 }\end{array}$ \\
\hline wealth decile $=3$ & $\begin{array}{l}0.0940^{* * *} \\
(7.92)\end{array}$ & $\begin{array}{l}0.153^{* * *} \\
(8.11)\end{array}$ \\
\hline wealth decile $=4$ & $\begin{array}{l}0.116^{* * *} \\
(8.39)\end{array}$ & $\begin{array}{l}0.194^{* * *} \\
(8.75)\end{array}$ \\
\hline wealth decile $=5$ & $\begin{array}{l}0.151^{* * *} \\
(9.74)\end{array}$ & $\begin{array}{l}0.255^{* * *} \\
(10.14)\end{array}$ \\
\hline wealth decile $=6$ & $\begin{array}{l}0.172^{* * *} \\
(10.62)\end{array}$ & $\begin{array}{l}0.293^{* * *} \\
(11.13)\end{array}$ \\
\hline wealth decile $=7$ & $\begin{array}{l}0.162^{* * *} \\
(9.98)\end{array}$ & $\begin{array}{l}0.273^{* * *} \\
(10.39)\end{array}$ \\
\hline wealth decile $=8$ & $\begin{array}{l}0.185^{* * *} \\
(10.94)\end{array}$ & $\begin{array}{l}0.315^{* * *} \\
(11.44)\end{array}$ \\
\hline wealth decile $=9$ & $\begin{array}{l}0.203^{* * *} \\
(11.98)\end{array}$ & $\begin{array}{l}0.348^{* * *} \\
(12.48)\end{array}$ \\
\hline wealth decile $=10$ & $\begin{array}{l}0.215^{* * *} \\
(12.53)\end{array}$ & $\begin{array}{l}0.375^{* * *} \\
(13.23)\end{array}$ \\
\hline home owner & $\begin{array}{l}-0.0380^{* * *} \\
(-3.26)\end{array}$ & $\begin{array}{l}-0.0706^{* * *} \\
(-3.76)\end{array}$ \\
\hline Germany & $\begin{array}{l}-0.0499^{* * *} \\
(-2.94)\end{array}$ & $\begin{array}{l}-0.0725^{* * *} \\
(-2.63)\end{array}$ \\
\hline Sweden & $\begin{array}{l}0.0817^{* * *} \\
(4.68)\end{array}$ & $\begin{array}{l}0.153^{* * *} \\
(5.39)\end{array}$ \\
\hline Netherlands & $\begin{array}{l}-0.141^{* * *} \\
(-9.13)\end{array}$ & $\begin{array}{l}-0.237^{* * *} \\
(-9.65)\end{array}$ \\
\hline Spain & $\begin{array}{l}-0.137^{* * *} \\
(-5.84)\end{array}$ & $\begin{array}{l}-0.226^{* * *} \\
(-6.09)\end{array}$ \\
\hline Italy & $\begin{array}{l}-0.134^{* * *} \\
(-7.81)\end{array}$ & $\begin{array}{l}-0.219^{* * *} \\
(-8.03)\end{array}$ \\
\hline France & $\begin{array}{l}-0.0354^{*} \\
(-1.93)\end{array}$ & $\begin{array}{l}-0.0562^{*} \\
(-1.91)\end{array}$ \\
\hline Denmark & $\begin{array}{l}-0.0368^{* *} \\
(-2.29)\end{array}$ & $\begin{array}{l}-0.0558^{* *} \\
(-2.17)\end{array}$ \\
\hline Switzerland & $\begin{array}{l}-0.0394^{* *} \\
(-2.26)\end{array}$ & $\begin{array}{l}-0.0616^{* *} \\
(-2.18)\end{array}$ \\
\hline Belgium & $\begin{array}{l}-0.101^{* * *} \\
(-5.91)\end{array}$ & $\begin{array}{l}-0.169^{* * *} \\
(-6.24)\end{array}$ \\
\hline Czech Republic & $\begin{array}{l}-0.000845 \\
(-0.04)\end{array}$ & $\begin{array}{l}-0.00472 \\
(-0.13)\end{array}$ \\
\hline Poland & $\begin{array}{l}-0.143^{* * *} \\
(-7.30)\end{array}$ & $\begin{array}{l}-0.233^{* * *} \\
(-7.46)\end{array}$ \\
\hline Observations & 4826 & 4826 \\
\hline
\end{tabular}

Note: The Table shows the Average Marginal Effect (AME) for post crisis and the other covariates. The base categories are age $<60.5$, no education, dependently working, not any risk, income $<25000.5$, wealth decile $=1$ and Austria. Standard errors are in pharanteses, significance levels: ${ }^{*} p<0.1,{ }^{* *} p<0.05,{ }^{* * *} p<0.01$. The AMEs for the variables are obtained by evaluating for each observation the discrete change of post crisis and the other discrete covariates. For the variable number of children a small $\epsilon$-change of the variable is applied. The derivative of DIV1 and DIV2 with respect to the covariates is computed and then averaged over the total of observations. For example, for post crisis we compute the predicted value using post crisis $=0$ and the observed values (cases) of the other variables to generate post crisis-Predict1. Then, we apply the discrete change $\Delta$ post crisis $=1$ and compute the newly predicted values for each case to generate post crisis-predict2. Finally, we compute $x m e=$ post crisis-predict $2-$ post crisis-predict 1 and calculate the mean value of xme. This procedure is equivalent to directly computing $\frac{\partial D I V I}{\partial \text { post crisis }}$ and, thus, the mean value of xme is the AME for post crisis. 
Table 10: Robustness check - Great Financial Crisis and Portfolio Diversity (Unbalanced Panel)

\begin{tabular}{|c|c|c|c|c|c|c|}
\hline & $\begin{array}{c}(1) \\
\text { DIV1 }\end{array}$ & $\begin{array}{c}(2) \\
\text { DIV2 } \\
\end{array}$ & $\begin{array}{c}(3) \\
\text { DIV1 }\end{array}$ & $\begin{array}{c}(4) \\
\text { DIV2 }\end{array}$ & $\begin{array}{c}(5) \\
\text { (DIV1) }\end{array}$ & $\begin{array}{c}(6) \\
\text { (DIV2) }\end{array}$ \\
\hline post crisis & $\begin{array}{l}-0.0140^{* * *} \\
(-4.15)\end{array}$ & $\begin{array}{l}-0.0233^{* * *} \\
(-4.21)\end{array}$ & $\begin{array}{l}-0.0124^{* * *} \\
(-3.77)\end{array}$ & $\begin{array}{l}-0.0204^{* * *} \\
(-3.80)\end{array}$ & $\begin{array}{l}-0.0113^{* * *} \\
(-3.45)\end{array}$ & $\begin{array}{l}-0.0185^{* * *} \\
(-3.46)\end{array}$ \\
\hline female & $\begin{array}{l}-0.0186^{* * *} \\
(-5.98)\end{array}$ & $\begin{array}{l}-0.0340^{* * *} \\
(-6.63)\end{array}$ & $\begin{array}{l}-0.0152^{* * *} \\
(-5.01)\end{array}$ & $\begin{array}{l}-0.0279^{* * *} \\
(-5.62)\end{array}$ & $\begin{array}{l}-0.0155^{* * *} \\
(-5.13)\end{array}$ & $\begin{array}{l}-0.0285^{* * *} \\
(-5.75)\end{array}$ \\
\hline $60.5 \leq$ age $<70.5$ & $\begin{array}{l}-0.00873^{* *} \\
(-2.05)\end{array}$ & $\begin{array}{l}-0.0160^{* *} \\
(-2.29)\end{array}$ & $\begin{array}{l}-0.0128^{* * *} \\
(-3.10)\end{array}$ & $\begin{array}{l}-0.0230^{* * *} \\
(-3.39)\end{array}$ & $\begin{array}{l}-0.0135^{* * *} \\
(-3.27)\end{array}$ & $\begin{array}{l}-0.0242^{* * *} \\
(-3.58)\end{array}$ \\
\hline $70.5 \leq$ age & $\begin{array}{l}-0.0457^{* * *} \\
(-9.81)\end{array}$ & $\begin{array}{l}-0.0769^{* * *} \\
(-10.13)\end{array}$ & $\begin{array}{l}-0.0466^{* * *} \\
(-10.29)\end{array}$ & $\begin{array}{l}-0.0785^{* * *} \\
(-10.66)\end{array}$ & $\begin{array}{l}-0.0484^{* * *} \\
(-10.71)\end{array}$ & $\begin{array}{l}-0.0817^{* * *} \\
(-11.10)\end{array}$ \\
\hline less than high school & $\begin{array}{l}0.0324^{* * *} \\
(4.52)\end{array}$ & $\begin{array}{l}0.0484^{* * *} \\
(4.28)\end{array}$ & $\begin{array}{l}0.0181^{* *} \\
(2.51)\end{array}$ & $\begin{array}{l}0.0239^{* *} \\
(2.10)\end{array}$ & $\begin{array}{l}0.0164^{* *} \\
(2.24)\end{array}$ & $\begin{array}{l}0.0210^{*} \\
(1.81)\end{array}$ \\
\hline high school & $\begin{array}{l}0.0692^{* * *} \\
(9.02)\end{array}$ & $\begin{array}{l}0.109^{* * *} \\
(8.95)\end{array}$ & $\begin{array}{l}0.0447^{* * *} \\
(5.81)\end{array}$ & $\begin{array}{l}0.0669^{* * *} \\
(5.49)\end{array}$ & $\begin{array}{l}0.0418^{* * *} \\
(5.37)\end{array}$ & $\begin{array}{l}0.0618^{* * *} \\
(5.00)\end{array}$ \\
\hline some university studies & $\begin{array}{l}0.107^{* * *} \\
(13.25)\end{array}$ & $\begin{array}{l}0.177^{* * *} \\
(13.68)\end{array}$ & $\begin{array}{l}0.0693^{* * *} \\
(8.50)\end{array}$ & $\begin{array}{l}0.111^{* * *} \\
(8.53)\end{array}$ & $\begin{array}{l}0.0663^{* * *} \\
(8.05)\end{array}$ & $\begin{array}{l}0.106^{* * *} \\
(8.03)\end{array}$ \\
\hline university degree & $\begin{array}{l}0.124^{\text {*** }} \\
(5.70)\end{array}$ & $\begin{array}{l}0.194^{* * *} \\
(5.42)\end{array}$ & $\begin{array}{l}0.0858^{* * *} \\
(4.09)\end{array}$ & $\begin{array}{l}0.128^{* * *} \\
(3.72)\end{array}$ & $\begin{array}{l}0.0817^{* * *} \\
(3.90)\end{array}$ & $\begin{array}{l}0.121^{* * *} \\
(3.51)\end{array}$ \\
\hline other education & $\begin{array}{l}0.0358^{*} \\
(1.77)\end{array}$ & $\begin{array}{l}0.0542^{*} \\
(1.66)\end{array}$ & $\begin{array}{l}0.0183 \\
(0.92)\end{array}$ & $\begin{array}{l}0.0243 \\
(0.76)\end{array}$ & $\begin{array}{l}0.0147 \\
(0.74)\end{array}$ & $\begin{array}{l}0.0181 \\
(0.56)\end{array}$ \\
\hline number of children & $\begin{array}{l}-0.00605^{* * *} \\
(-6.17)\end{array}$ & $\begin{array}{l}-0.00998^{* * *} \\
(-6.26)\end{array}$ & $\begin{array}{l}-0.00499^{* * *} \\
(-5.24)\end{array}$ & $\begin{array}{l}-0.00823^{* * *} \\
(-5.32)\end{array}$ & $\begin{array}{l}-0.00479^{* * *} \\
(-5.03)\end{array}$ & $\begin{array}{l}-0.00788^{* * *} \\
(-5.11)\end{array}$ \\
\hline married & $\begin{array}{l}0.0216^{* * *} \\
(6.45)\end{array}$ & $\begin{array}{l}0.0350^{* * *} \\
(6.41)\end{array}$ & $\begin{array}{l}0.00247 \\
(0.75)\end{array}$ & $\begin{array}{l}0.00260 \\
(0.48)\end{array}$ & $\begin{array}{l}0.00347 \\
(1.05)\end{array}$ & $\begin{array}{l}0.00434 \\
(0.81)\end{array}$ \\
\hline dependent working & $\begin{array}{l}-0.0749 \\
(-0.66)\end{array}$ & $\begin{array}{l}-0.101 \\
(-0.55)\end{array}$ & $\begin{array}{l}-0.0626 \\
(-0.50)\end{array}$ & $\begin{array}{l}-0.0797 \\
(-0.39)\end{array}$ & $\begin{array}{l}-0.0582 \\
(-0.46)\end{array}$ & $\begin{array}{l}-0.0720 \\
(-0.35)\end{array}$ \\
\hline self-employed & $\begin{array}{l}-0.0796 \\
(-0.70)\end{array}$ & $\begin{array}{l}-0.104 \\
(-0.57)\end{array}$ & $\begin{array}{l}-0.0918 \\
(-0.73)\end{array}$ & $\begin{array}{l}-0.126 \\
(-0.62)\end{array}$ & $\begin{array}{l}-0.0887 \\
(-0.70)\end{array}$ & $\begin{array}{l}-0.121 \\
(-0.59)\end{array}$ \\
\hline other occupation & $\begin{array}{l}-0.109 \\
(-0.96)\end{array}$ & $\begin{array}{l}-0.158 \\
(-0.86)\end{array}$ & $\begin{array}{l}-0.0956 \\
(-0.76)\end{array}$ & $\begin{array}{l}-0.135 \\
(-0.67)\end{array}$ & $\begin{array}{l}-0.0908 \\
(-0.72)\end{array}$ & $\begin{array}{l}-0.127 \\
(-0.62)\end{array}$ \\
\hline retiree & $\begin{array}{l}-0.102 \\
(-0.90)\end{array}$ & $\begin{array}{l}-0.151 \\
(-0.83)\end{array}$ & $\begin{array}{l}-0.0926 \\
(-0.74)\end{array}$ & $\begin{array}{l}-0.134 \\
(-0.66)\end{array}$ & $\begin{array}{l}-0.0882 \\
(-0.70)\end{array}$ & $\begin{array}{l}-0.126 \\
(-0.62)\end{array}$ \\
\hline unemployed & $\begin{array}{l}-0.143 \\
(-1.25)\end{array}$ & $\begin{array}{l}-0.215 \\
(-1.18)\end{array}$ & $\begin{array}{l}-0.111 \\
(-0.88)\end{array}$ & $\begin{array}{l}-0.161 \\
(-0.80)\end{array}$ & $\begin{array}{l}-0.108 \\
(-0.85)\end{array}$ & $\begin{array}{l}-0.155 \\
(-0.76)\end{array}$ \\
\hline $25000.5 \leq$ inc. $<50000.5$ & $\begin{array}{l}0.0594^{* * *} \\
(15.46)\end{array}$ & $\begin{array}{l}0.101^{* * *} \\
(16.03)\end{array}$ & $\begin{array}{l}0.0419^{* * *} \\
(11.12)\end{array}$ & $\begin{array}{l}0.0706^{* * *} \\
(11.52)\end{array}$ & $\begin{array}{l}0.0411^{* * *} \\
(10.93)\end{array}$ & $\begin{array}{l}0.0692^{* * *} \\
(11.32)\end{array}$ \\
\hline $50000.5 \leq$ inc. $<100000.5$ & $\begin{array}{l}0.0919^{* * *} \\
(16.95)\end{array}$ & $\begin{array}{l}0.164^{* * *} \\
(18.06)\end{array}$ & $\begin{array}{l}0.0629^{* * *} \\
(11.80)\end{array}$ & $\begin{array}{l}0.113^{* * *} \\
(12.75)\end{array}$ & $\begin{array}{l}0.0629^{* * *} \\
(11.83)\end{array}$ & $\begin{array}{l}0.113^{* * *} \\
(12.78)\end{array}$ \\
\hline $100000.5 \leq$ inc. & $\begin{array}{l}0.105^{* * *} \\
(12.43)\end{array}$ & $\begin{array}{l}0.188^{* * *} \\
(13.12)\end{array}$ & $\begin{array}{l}0.0733^{* * *} \\
(8.96)\end{array}$ & $\begin{array}{l}0.133^{* * *} \\
(9.62)\end{array}$ & $\begin{array}{l}0.0735^{* * *} \\
(8.98)\end{array}$ & $\begin{array}{l}0.133^{* * *} \\
(9.65)\end{array}$ \\
\hline wealth decile $=2$ & & & $\begin{array}{l}0.0583^{* * *} \\
(12.25)\end{array}$ & $\begin{array}{l}0.0934^{* * *} \\
(12.40)\end{array}$ & $\begin{array}{l}0.0613^{* * *} \\
(12.75)\end{array}$ & $\begin{array}{l}0.0987^{* * *} \\
(12.93)\end{array}$ \\
\hline wealth decile $=3$ & & & $\begin{array}{l}0.0851^{* * *} \\
(16.90)\end{array}$ & $\begin{array}{l}0.135^{* * *} \\
(17.06)\end{array}$ & $\begin{array}{l}0.102^{* * *} \\
(17.82)\end{array}$ & $\begin{array}{l}0.164^{* * *} \\
(18.13)\end{array}$ \\
\hline wealth decile $=4$ & & & $\begin{array}{l}0.101^{* * *} \\
(19.32)\end{array}$ & $\begin{array}{l}0.161^{* * *} \\
(19.38)\end{array}$ & $\begin{array}{l}0.127^{* * *} \\
(19.42)\end{array}$ & $\begin{array}{l}0.207^{* * *} \\
(19.65)\end{array}$ \\
\hline wealth decile $=5$ & & & $\begin{array}{l}0.114^{* * *} \\
(20.97)\end{array}$ & $\begin{array}{l}0.186^{* * *} \\
(21.24)\end{array}$ & $\begin{array}{l}0.146^{* * *} \\
(20.34)\end{array}$ & $\begin{array}{l}0.243^{* * *} \\
(20.60)\end{array}$ \\
\hline wealth decile $=6$ & & & $\begin{array}{l}0.119^{* * *} \\
(21.57)\end{array}$ & $\begin{array}{l}0.196^{* * *} \\
(21.79)\end{array}$ & $\begin{array}{l}0.155^{* * *} \\
(20.51)\end{array}$ & $\begin{array}{l}0.258^{* * *} \\
(20.79)\end{array}$ \\
\hline wealth decile $=7$ & & & $\begin{array}{l}0.135^{* * *} \\
(23.98)\end{array}$ & $\begin{array}{l}0.219^{* * *} \\
(24.01)\end{array}$ & $\begin{array}{l}0.172^{* * *} \\
(22.55)\end{array}$ & $\begin{array}{l}0.283^{* * *} \\
(22.80)\end{array}$ \\
\hline wealth decile $=8$ & & & $\begin{array}{l}0.149^{* * *} \\
(25.45)\end{array}$ & $\begin{array}{l}0.246^{* * *} \\
(25.71)\end{array}$ & $\begin{array}{l}0.186^{* * *} \\
(23.78)\end{array}$ & $\begin{array}{l}0.310^{* * *} \\
(24.22)\end{array}$ \\
\hline wealth decile $=9$ & & & $\begin{array}{l}0.172^{* * *} \\
(28.53)\end{array}$ & $\begin{array}{l}0.292^{* * *} \\
(29.10)\end{array}$ & $\begin{array}{l}0.209^{* * *} \\
(26.32)\end{array}$ & $\begin{array}{l}0.356^{* * *} \\
(27.17)\end{array}$ \\
\hline wealth decile $=10$ & & & $\begin{array}{l}0.191^{* * *} \\
(30.50)\end{array}$ & $\begin{array}{l}0.328^{* * *} \\
(31.28)\end{array}$ & $\begin{array}{l}0.228^{* * *} \\
(27.86)\end{array}$ & $\begin{array}{l}0.392^{* * *} \\
(28.91)\end{array}$ \\
\hline home owner & & & & & $-0.0404^{* * *}$ & $-0.0703^{* * *}$ \\
\hline
\end{tabular}


Table 10: Determinants of individual diversity: unbalanced panel for Robustness

\begin{tabular}{|c|c|c|c|c|c|c|}
\hline & $\begin{array}{c}(1) \\
\text { DIV1 }\end{array}$ & $\begin{array}{c}(2) \\
\text { DIV2 }\end{array}$ & $\begin{array}{c}(3) \\
\text { DIV1 }\end{array}$ & $\begin{array}{c}(4) \\
\text { DIV2 }\end{array}$ & $\begin{array}{c}(5) \\
\text { DIV1 }\end{array}$ & $\begin{array}{c}(6) \\
\text { DIV2 }\end{array}$ \\
\hline \multirow{3}{*}{ Constant } & & & & & $(-7.31)$ & $(-7.80)$ \\
\hline & $0.235^{* *}$ & $0.371^{* *}$ & 0.153 & 0.237 & 0.146 & 0.224 \\
\hline & $(2.05)$ & $(2.02)$ & (1.21) & (1.16) & (1.15) & (1.10) \\
\hline Observations & 20848 & 20848 & 20848 & 20848 & 20848 & 20848 \\
\hline
\end{tabular}

Country dummies included. $t$ statistics in parentheses, ${ }^{*} p<0.10,{ }^{* *} p<0.05,{ }^{* * *} p<0.01$.

Note: We apply regression Equation (3) to estimate the effect of socio-demographic, time-independent and time-dependent variables on DIV1 (Gini-Simpson Index, Equation (1)) and DIV2 (Shannon-Entropy Index, Equation (2)). The OLS regression uses an unbalanced panel with pooled data across both waves. Standard errors are robust. The base categories are age $<60.5$, no education, dependently working, not any risk, income $<25000.5$ and wealth decile $=1$. Respective countries are considered in the form of country dummies. 